\title{
Measurement of Air Pollution in Kuwait City Using Passive Samplers
}

\author{
Jasem M. Al-Awadhi \\ Department of Earth and Environmental Sciences, Faculty of Science, Kuwait University, Kuwait City, Kuwait \\ Email: jawadhi@kuc01.kuniv.edu.kw, jawadhi1@live.com
}

Received 5 February 2014; revised 1 March 2014; accepted 8 March 2014

Copyright (C) 2014 by author and Scientific Research Publishing Inc.

This work is licensed under the Creative Commons Attribution International License (CC BY). http://creativecommons.org/licenses/by/4.0/

(c) (1) Open Access

\begin{abstract}
Measurements of gaseous $\mathrm{SO}_{2}, \mathrm{NO}, \mathrm{NO}_{2}, \mathrm{H}_{2} \mathrm{~S}, \mathrm{O}_{3}, \mathrm{NH}_{3}$ and VOCs, in Kuwait city using IVL passive sampler technology, were obtained on monthly basis during the period from March 2011 to February 2012 at 10 locations. The results of this study reveal that those compounds had low concentrations compared to Kuwait Environment Public Authority standards for residential areas. It is found that nitrogen oxides, benzene and xylene were mostly emitted from motor vehicles; in contrast, industrial sources including oil industries were a major contributor to sulfur dioxide and toluene pollution. Higher concentrations of $\mathrm{NO}_{\mathrm{x}}$ and $\mathrm{SO}_{2}$ were recorded during winter season where the inversion layer is quite pronounced thus trapping more pollutants in ambient air, while higher $\mathrm{O}_{3}$ values were recorded in summer period; the hot season in Kuwait. The spatial distributions of the measured gaseous air pollutants were extremely consistent with the influence of the prevailing wind direction NW. In general and except for $\mathbf{P M}_{10}$, the yearly average air quality indices (AQI) of $\mathrm{SO}_{2}, \mathrm{NO}_{2}, \mathrm{CO}$ and $\mathrm{O}_{3}$ concentrations are coming under the category of "good" and "moderate".
\end{abstract}

\section{Keywords}

Passive Sampler; $\mathrm{SO}_{2} ; \mathrm{NO} ; \mathrm{NO}_{2} ; \mathrm{H}_{2} \mathrm{~S} ; \mathrm{O}_{3} ; \mathrm{NH}_{3}$; VOCs; Quality Indices

\section{Introduction}

The State of Kuwait has experienced a very rapid growth rate in the socio-economic and infrastructures over the last four decades. The construction of hundreds of kilometres of urban freeways and arterials has complemented the intense development of the socio-economic sectors. With a population of over three million and a vehicle fleet of more than one million and both growing rapidly, Kuwait City is experiencing increasing volumes of traffic, greater trip frequency and increasing trip length [1]. Thus the outdoor air quality is becoming a major air pollution issue and concern, for the people living in Kuwait City, due to its use for indoor ventalation. It also remains 
among the key problems of urban environment. Non-methane hydrocarbon concentrations in the ambient air are generally elevated with respect to Kuwait Environment Public Authority (K-EPA) limits [2]; suggesting oil related activities are the causative agents.

In a survey of more than 100 cities in industrial and non-industrial countries, the World Bank has found that the air in many urban areas remains unhealthy [3]. The study survey indicated that nearly $29 \%$ of the surveyed cities experienced sulphur dioxide concentrations (often from power plants) in excess of the maximum levels allowable under WHO guidelines and $71 \%$ had nitrogen dioxide concentrations (often from urban traffic) that exceeded WHO maximums [1]. The interaction of primary pollutants with the surrounding environment and the effect of photochemical reactions in the atmosphere results in what is known as secondary pollutants, a valid example of which is ozone $\left(\mathrm{O}_{3}\right)$. The rate of the conversion of $\mathrm{NO}_{\mathrm{x}}$ to $\mathrm{NO}_{3}$ affects ozone formation and the fate of the $\mathrm{NO}_{\mathrm{x}}$ in the atmosphere. $\mathrm{NO}_{\mathrm{x}}$ is oxidized to Nitric acid $\left(\mathrm{HNO}_{3}\right)$ in the atmosphere, which in turn forms $\mathrm{NO}_{3}$ particles [4].

Seven years (1998-2004) of data from three Air Monitoring Stations of Kuwait Environmental Public Authority (KEPA) were analyzed by Al-Mutairi and Koushki [1]. The analyses of the data showed that concentrations of the following air pollutants $\mathrm{CH}_{4}, \mathrm{CO}, \mathrm{O}_{3}, \mathrm{SO}_{2}, \mathrm{NO}_{x}$ and total sulfur (TS), had slightly increased over the seven-year study period and only those of the $\mathrm{NO}_{\mathrm{x}}$ and $\mathrm{SO}_{2}$ exceed the permitted standard levels. Traffic was the main source of air pollution in the district located adjacent to the Kuwait city centre, while oil refineries contributed most to ambient air pollution in the rural district. However, the review of literature indicates that no analysis of air pollution trend or source identification in Kuwait city has been made in recent years. It is the narrowing of this research gap that this study addresses. This study focused on measurements of selected gaseous air pollutants in outdoor ambient air in the vicinity of Kuwait city using passive samplers. The pollutants addressed are sulphur dioxide $\left(\mathrm{SO}_{2}\right)$, nitrogen monoxide and dioxide $\left(\mathrm{NO}, \mathrm{NO}_{2}\right)$, hydrogen sulfide $\left(\mathrm{H}_{2} \mathrm{~S}\right)$, ozone $\left(\mathrm{O}_{3}\right)$, ammonia $\left(\mathrm{NH}_{3}\right)$, and Total Volatile Organic Compound (TVOC). All the measurements were performed simultaneously to ensure optimal use of time and effort.

\section{Pollution Load in the Study Area}

Kuwait City, the capital city of Kuwait, is located at the eastern part of the country on the shore of the Arabian Gulf with an estimated current population of 56,200. It contains most governmental offices, the headquarters of most Kuwaiti corporations and banks. It is the political, cultural and economic center of the state. Automobiles are, by far, the principle mode of travel in Kuwait city. Traffic congestion and rush hours within city limits and along major highways surrounding the city (i.e., $1^{\text {st }}$ to $5^{\text {th }}$ ring road) contribute mainly to the $\mathrm{CO}, \mathrm{NO}_{\mathrm{x}}$ and VOCs levels in the air [5]. The average hourly number of vehicles running on the main roads in Kuwait city ranges from 611 to 2792 vehicles/hr (Figure 1). The data, collected from a traffic survey carried by the Ministry of Interior in October 2010 for one week, showed marked day-of-week dependence.

Activities within the city harbor (Mina Shuwaikh port) also contribute to the traffic-related airborne pollutants and pollution load. While traffic is the main source of air pollution in Kuwait City, upstream/downstream Industries such as power stations and oil fields and refineries contribute the least to air pollution emissions in the city (Figure 2). Three major refineries process over 935,000 bbld, situated in the southern part of the country, collectively referred to as the refineries belt [6]. In addition, petrochemical processing lines and conversion Industries are all located, somewhat, in the vicinity of this belt (Figure 2). The capacity of the power plant and desalination network in the country is estimated at 16,095 MW and $2 \times 10^{6} \mathrm{~m}^{3} /$ day, respectively [6]. The northern power plants (operating on fossil fuels) are expected to be main sources for $\mathrm{SO}_{2}$ and $\mathrm{NO}_{\mathrm{x}}$ pollutants in Kuwait city. The emissions of these pollutants from the oil fields are also possible sources in the vicinity of Kuwait city and its surroundings. Kuwait city is also affected by possible emissions of $\mathrm{H}_{2} \mathrm{~S}$ and $\mathrm{NH}_{3}$, which are generated from existing old landfills in the vicinity of the city and agricultural activities, respectively.

\section{Materials and Methods}

Passive (diffusive) samplers were used at 10 locations in Kuwait city to measure the following components: $\mathrm{SO}_{2}$, $\mathrm{NO}, \mathrm{NO}_{2}, \mathrm{H}_{2} \mathrm{~S}, \mathrm{O}_{3}, \mathrm{NH}_{3}$, and VOCs (Benzene, Toluene, n-Octane, Ethyl Benzene, m\&p-Xylene, o-Xylene and Nonane). Each of these components was sampled on a monthly basis. Measurements began in March 2011 and were conducted for 12 months. The 10 sampling locations (Figure 3) were systematically selected over Kuwait 


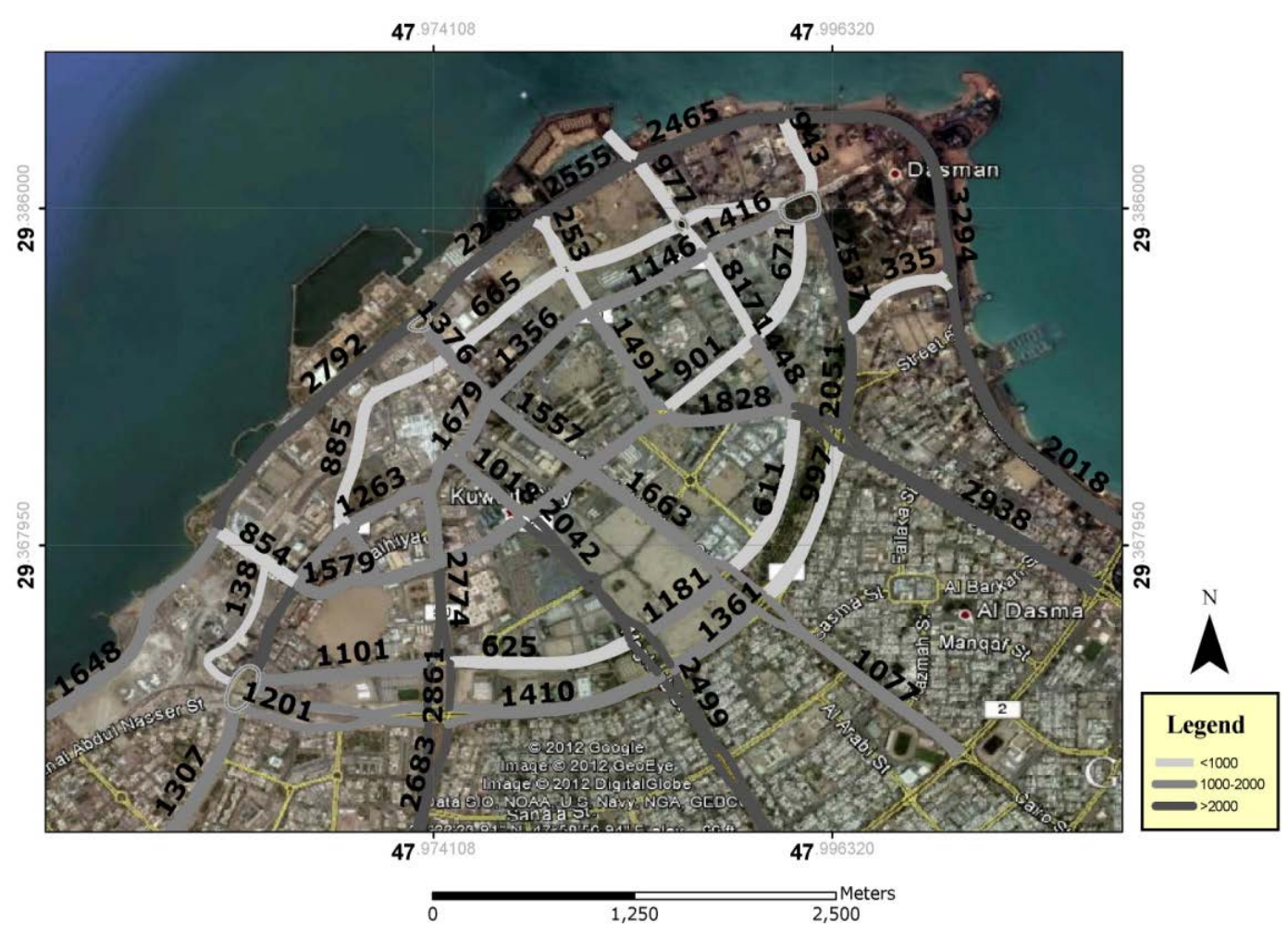

Figure 1. Average hourly number of vehicles running on the main roads in Kuwait City during the day time.

city with a density of approximately one sample per half-square kilometer. Sites were chosen, wherever possible, to be away from direct local sources, including roads. This study utilized diffusive samplers developed at the IVL (Swedish Environmental Research Institute Ltd—Gothenburg, Sweden) and described in the literature [7]. The IVL samplers are of badge type, $10 \mathrm{~mm}$ long and $20 \mathrm{~mm}$ internal diameter. A membrane is mounted at the inlet to prevent them from wind-induced turbulent diffusion. The membrane is protected from mechanical damage by a stainless steel mesh.

The samplers were mounted under a metal disc in order to protect them from rain and direct sunshine (Figure 4), and fixed at a height $3 \mathrm{~m}$ above the ground. Even in the absence of rain, the shelter is required to minimize dust contamination and the effects of advection on the diffusive samplers. Based on the passive sampler manufacturer's advice, the samplers were left in the field for about three weeks. Description of the sampling protocol is presented in Table 1. The samplers were prepared at IVL and mailed together with instructions on a monthly basis to the author. The samplers were transported to and from the field in air-tight containers, and minimally handled in the field using latex gloves. The samplers were then sent to IVL for analysis. At IVL, the analytical procedures for the samplers have been accredited. Furthermore, the IVL is participating in the standardization work for testing diffusive samplers within the CEN (European Committee for Standardization). This implies that certified standards are used every time a batch of samples is analyzed. Additional information of the use of IVL-type samplers and their comparison with active sampling results can be found in Ayers et al. [8] [9] and Gillett et al. [10].

The sampler sites were then geo-referenced and registered to a base-map and the data imported into a surfer software version 10. Statistical data processing was performed using SPSS software package version 19. The data set, consisting of $n$ elements $(n=120)$, was treated as a 3-dimensional statistical sample defined as:

$$
x=x_{i j k} ;\left\{\begin{array}{c}
i \in \text { pollutent [NO } \cdots \text { xylene] } \\
j \in \text { location [1....10] } \\
k \in \text { month [Jan } \cdots \text { Dec] }
\end{array}\right\}
$$

where $i$ is the air pollutant; $j$ the site ID; $k$ the month ID; $x$ the concentration of the air pollutant $i$ at site $j$ during 


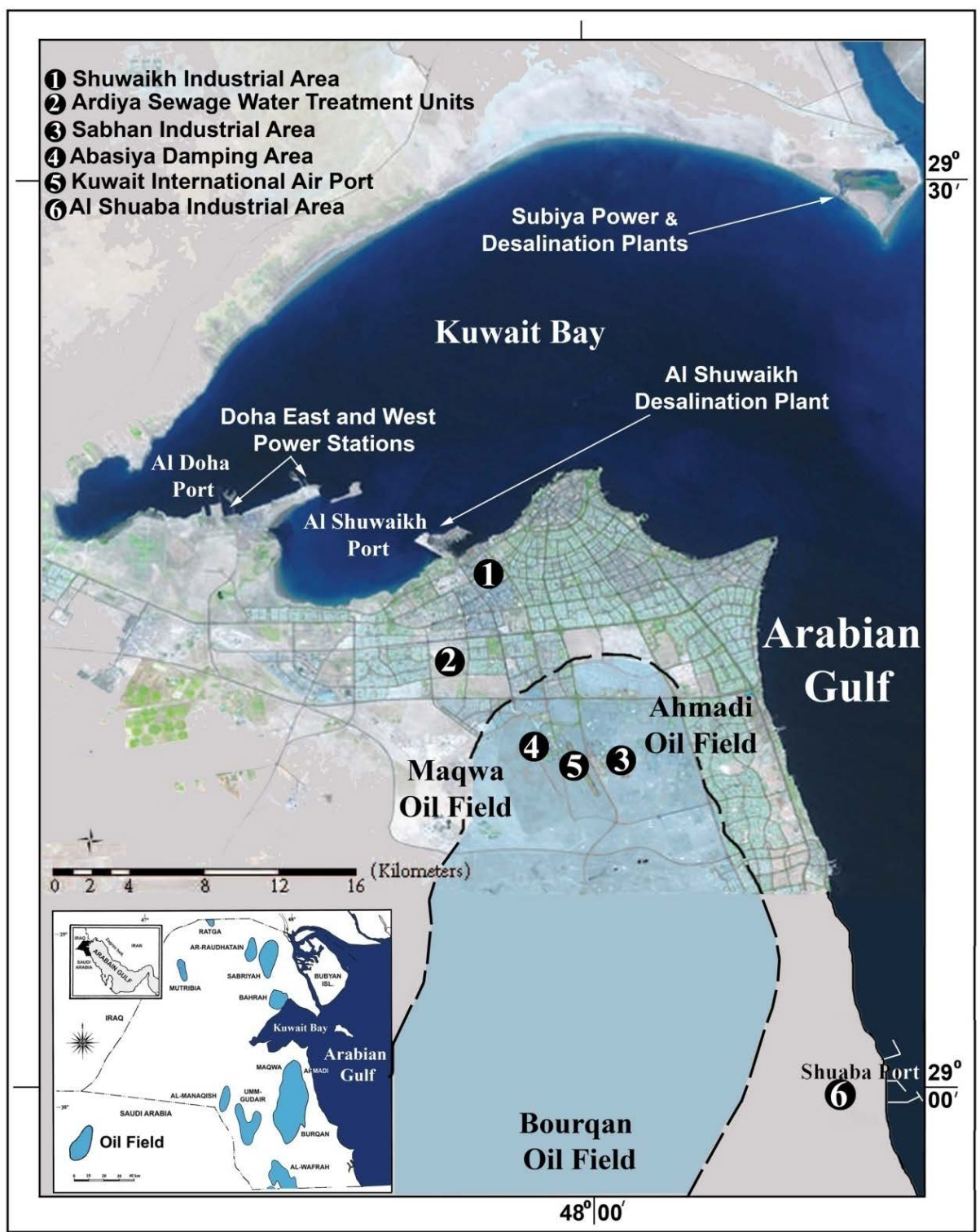

Figure 2. Possible local sources of pollutants to Kuwait City.

the $k^{\text {th }}$ month.

Furthermore, to correlate the concentrations of the measured pollutants with the meteorological conditions, the meteorological data for the period of the sampling were also obtained from Kuwait International Airport.

In the present work, the air quality was also assessed through the use of Air Quality index developed by Al-Shayji et al. [11] for the State of Kuwait, based on the guidelines proposed by the US Environmental Protection Agency [12]. Table 2 shows the AQI ranges, corresponding health effects and associated category codes suggested by the US-EPA. For this purpose continuous measurements of $\mathrm{SO}_{2}, \mathrm{PM}_{10}, \mathrm{NO}_{2}, \mathrm{O}_{3}$ and $\mathrm{CO}$, corresponding to a period between March 2011 and February 2012, were used. Specifically, the pollution level timeseries were obtained from the Mansouria monitoring station. Mansouria is a district adjacent to the Kuwait city center; i.e., $3 \mathrm{~km}$ from the centre. At the station, $\mathrm{PM}_{10}, \mathrm{CO}, \mathrm{NO}, \mathrm{NO}_{2}, \mathrm{O}_{3}$ and $\mathrm{SO}_{2}$ concentrations are routinely recorded.

In the station, $\mathrm{SO}_{2}$ and $\mathrm{CO}$ concentrations are measured through the UV-fluorescence principle and the infrared correlation photometry method respectively, while the Beta-gauge method is used to measure $\mathrm{PM}_{10}$ concentrations. On the other hand, the ozone concentrations are continuously measured through the UV-absorption 


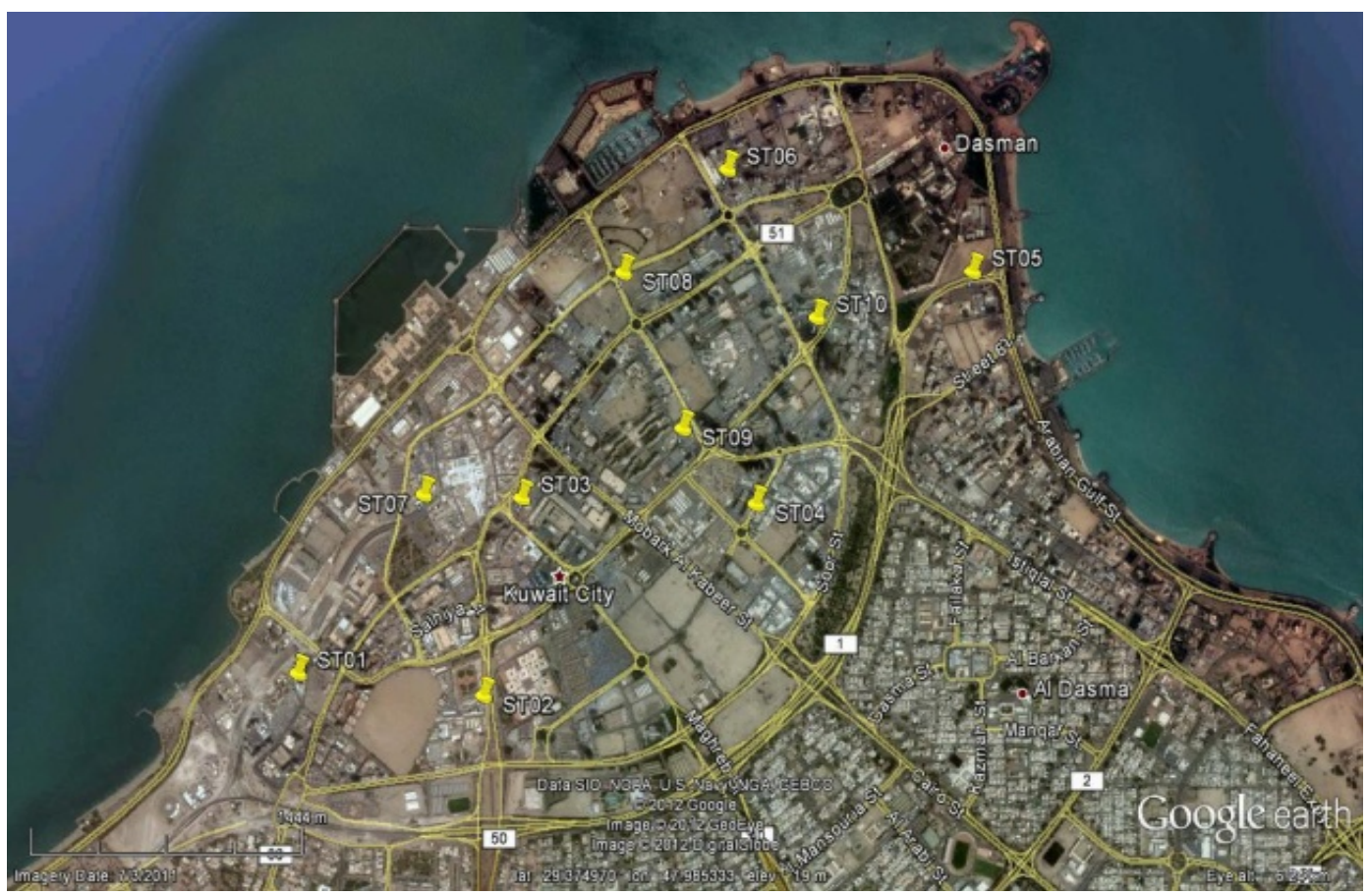

Figure 3. Location of the measurement sites used in this study.

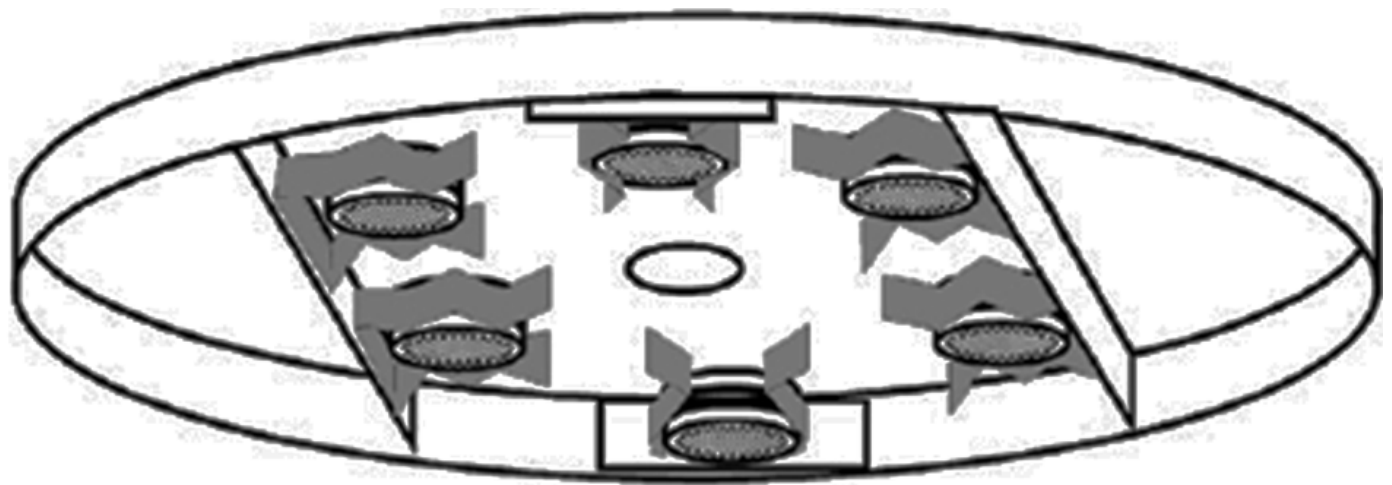

Figure 4. Passive samplers mounted under a metal disc..

method, whereas $\mathrm{NO}$ and $\mathrm{NO}_{2}$ measurements are performed through the chemilumine science principle. It is noted that all analyzers are calibrated regularly through calibration units (gas cylinders, permeation tubes, reference gauges, pre-weighed calibration filters and mass flow controllers).

\section{Results and Discussion}

\subsection{Basic Analysis}

Table 3 lists the average results for individual pollutant, detected by the passive samplers at 10 sites for a period of 12 months, including the mean concentrations, coefficients of variation and maximum and minimum values. Most pollutants show a consistency between their median and mean concentrations. The largest disagreements occurred for NO; this may be due to indirect measurement of NO; i.e., $\mathrm{NO}_{\mathrm{x}}$ and $\mathrm{NO}_{2}$ concentrations were considered to calculate $\mathrm{NO}$ value as difference, thus the experimental errors of both $\mathrm{NO}_{2}$ and $\mathrm{NO}_{\mathrm{x}}$ measurements may be included.

Statistically, Table 3 indicates that the variation in the concentrations among each measured pollutant ranges between 40 to $46 \%$. Also, the mean values are found to be greater than the median values leading to positively 
Table 1. Description of the sampling protocol.

\begin{tabular}{|c|c|c|c|c|c|c|c|}
\hline \multirow{2}{*}{ Month } & \multicolumn{2}{|c|}{ Sampling duration } & \multirow{2}{*}{$\begin{array}{c}\text { Temp } \\
{ }^{\circ} \mathrm{C}\end{array}$} & \multirow{2}{*}{ Humidity \% } & \multirow{2}{*}{$\begin{array}{c}\text { WD } \\
{ }^{\circ} \mathbf{N}\end{array}$} & \multirow{2}{*}{$\begin{array}{l}\text { WS } \\
\mathbf{m} / \mathbf{s}\end{array}$} & \multirow{2}{*}{ Pressure m Bars } \\
\hline & Start & End & & & & & \\
\hline March & $03 / 03 / 2011$ & $26 / 3 / 2011$ & 19.75 & 46.17 & 213.14 & 3.81 & 1013.60 \\
\hline April & 04/08/2011 & $23 / 4 / 2011$ & 25.49 & 43.19 & 155.69 & 3.77 & 1007.25 \\
\hline May & 05/07/2011 & 22/5/2012 & 32.31 & 37.58 & 134.14 & 3.47 & 996.13 \\
\hline June & 06/11/2011 & $30 / 6 / 2011$ & 36.81 & 30.80 & 234.38 & 3.82 & 994.43 \\
\hline July & 16/7/2011 & $31 / 7 / 2011$ & 38.04 & 32.68 & 204.67 & 3.38 & 994.89 \\
\hline August & 08/01/2011 & $16 / 8 / 2011$ & 38.08 & 33.61 & 195.70 & 3.34 & 1000.00 \\
\hline September & 09/05/2011 & 20/9/2011 & 35.06 & 38.10 & 130.77 & 3.42 & 1008.62 \\
\hline October & $14 / 10 / 2011$ & $31 / 10 / 2011$ & 28.55 & 43.37 & 171.01 & 3.51 & 1014.27 \\
\hline November & $16 / 11 / 2011$ & $30 / 11 / 2011$ & 20.35 & 51.12 & 211.51 & 4.26 & 1019.65 \\
\hline December & $12 / 02 / 2011$ & $21 / 12 / 2011$ & 15.07 & 55.16 & 253.84 & 3.96 & 1019.65 \\
\hline January & $01 / 01 / 2012$ & 28/1/2012 & 15.83 & 51.12 & 187.43 & 4.07 & 1016.74 \\
\hline February & 02/10/2012 & 03/02/2012 & 15.76 & 55.96 & 195.84 & 3.66 & 1012.89 \\
\hline
\end{tabular}

Table 2. AQI range, description and corresponding category codes suggested by Al-Shayji et al. [11] and the US Environmental Protection Agency.

\begin{tabular}{|c|c|c|c|c|c|c|}
\hline \multirow[b]{2}{*}{ Categories } & \multicolumn{6}{|c|}{ Breakpoints for each pollutant } \\
\hline & $\begin{array}{c}\text { AQI } \\
\text { Sub-Index }\end{array}$ & $\begin{array}{c}\mathrm{O}_{3} \text { (ppm) } \\
\text { 8-hour }\end{array}$ & $\begin{array}{c}\text { PM10 }\left(\mu \mathrm{g} / \mathrm{m}^{3}\right) \\
\text { 24-hour }\end{array}$ & $\begin{array}{l}\text { CO (ppm) } \\
\text { 24-hour }\end{array}$ & $\begin{array}{c}\mathrm{SO}_{2}(\mathrm{ppm}) \\
\text { 24-hour }\end{array}$ & $\begin{array}{c}\mathrm{NO}_{2}(\mathrm{ppm}) \\
\text { 24-hour }\end{array}$ \\
\hline Good & $0-50$ & $\begin{array}{c}0.0-0.03^{\mathrm{a}} \\
(0.0-0.064)^{\mathrm{b}}\end{array}$ & $\begin{array}{l}0.0-90 \\
(0-54)\end{array}$ & $\begin{array}{c}0.0-4.0 \\
(0.0-4.4)\end{array}$ & $\begin{array}{c}0.0-0.03 \\
(0.0-0.034)\end{array}$ & $\begin{array}{c}0.0-0.03 \\
\left({ }^{c}\right)\end{array}$ \\
\hline Moderate & $51-100$ & $\begin{array}{c}0.031-0.06 \\
(0.065-0.084)\end{array}$ & $\begin{array}{c}90.1-350.0 \\
(55-154)\end{array}$ & $\begin{array}{c}4.1-8.0 \\
(4.5-9.4)\end{array}$ & $\begin{array}{c}0.031-0.06 \\
(0.035-0.144)\end{array}$ & $\begin{array}{c}0.04-0.05 \\
\left({ }^{\mathrm{C}}\right)\end{array}$ \\
\hline $\begin{array}{l}\text { Unhealthy for } \\
\text { sensitive groups }\end{array}$ & $101-150$ & $\begin{array}{c}0.061-0.092 \\
(0.085-0.104)\end{array}$ & $\begin{array}{c}350.1-431.3 \\
(155-254)\end{array}$ & $\begin{array}{c}8.1-11.7 \\
(9.5-12.4)\end{array}$ & $\begin{array}{c}0.061-0.182 \\
(0.145-0.224)\end{array}$ & $\begin{array}{c}0.06-0.30 \\
\left({ }^{C}\right)\end{array}$ \\
\hline Unhealthy & $151-200$ & $\begin{array}{c}0.093-0.124 \\
(0.105-0.124)\end{array}$ & $\begin{array}{c}431.4-512.5 \\
(255-354)\end{array}$ & $\begin{array}{c}11.8-15.4 \\
(12.5-15.4)\end{array}$ & $\begin{array}{c}0.183-0.304 \\
(0.225-0.304)\end{array}$ & $\begin{array}{c}0.31-0.55 \\
\left({ }^{c}\right)\end{array}$ \\
\hline Very Unhealthy & $201-300$ & $\begin{array}{c}0.125-0.374 \\
(0.125-0.404)\end{array}$ & $\begin{array}{c}512.6-675.0 \\
(355-424)\end{array}$ & $\begin{array}{c}15.5-30.4 \\
(15.5-30.4)\end{array}$ & $\begin{array}{c}0.305-0.604 \\
(0.305-0.604)\end{array}$ & $\begin{array}{r}0.65-1.04 \\
(0.65-1.24)\end{array}$ \\
\hline $\begin{array}{l}\text { Hazardous1 } \\
\text { Hazardous2 }\end{array}$ & $\begin{array}{l}301-400 \\
401-500\end{array}$ & $\begin{array}{c}0.375-0.504 \\
(0.405-0.504) \\
0.505-0.604 \\
(0.505-0.604)\end{array}$ & $\begin{array}{c}675.1-837.5 \\
(425-504) \\
837.6-1000 \\
(505-604)\end{array}$ & $\begin{array}{c}30.5-40.4 \\
(30.5-40.4) \\
40.5-50.4 \\
(40.5-50.4)\end{array}$ & $\begin{array}{c}0.605-0.804 \\
0.605-0.804) \\
0.805-1.004 \\
0.805-1.004\end{array}$ & $\begin{array}{r}1.05-1.54 \\
(1.25-1.64) \\
1.55-2.04 \\
1.65-2.04\end{array}$ \\
\hline
\end{tabular}

${ }^{\mathrm{a}}$ Break points for Kuwait AQI, ${ }^{\mathrm{b}}$ Break points for US AQI, ${ }^{\mathrm{c}} \mathrm{NO}_{2}$ has no short term US NAAQS \& can generate an AQI only above a value of 200.

skewness values (except for $\mathrm{NH}_{3}$ ); i.e., values approaching to zero from positive direction. Thus, we can consider those pollutants are stabled under these circumstances.

The air pollutant concentrations for each pollutant $i$ broken down by sampling site $j$ and sampling month $k$; i.e., $x=x_{i j k}$ (Equation (1)), are presented in Figure 5. It is important to keep in mind the following point when discussing the experimental data. The diffusive samplers are suitable to describe the spatial distribution of air pollutants simply because they can only integrate exposures to give a cumulative value of all the hourly fluctuations in pollutant gas concentrations.

A comparison between the measured concentrations and the applicable air quality standards promulgated by Kuwait EPA, as well as US EPA, reveals the following:

1) The maximum measured concentration $\left(8.0 \mu \mathrm{g} / \mathrm{m}^{3}\right)$ of $\mathrm{NH}_{3}$ is low value compared to the annual KEPA residential standard $\left(148 \mu \mathrm{g} / \mathrm{m}^{3}\right)$ for $\mathrm{NH}_{3}$.

2) The maximum measured concentration $\left(35.6 \mu \mathrm{g} / \mathrm{m}^{3}\right)$ of $\mathrm{NO}_{2}$ is lower than the KEPA annual standard (67 $\mu \mathrm{g} / \mathrm{m}^{3}$ ) for residential areas for $\mathrm{NO}_{2}$.

3) The maximum measured concentration $\left(20.2 \mu \mathrm{g} / \mathrm{m}^{3}\right)$ of $\mathrm{SO}_{2}$ is about one quarter of the yearly KEPA residential standard $\left(80 \mu \mathrm{g} / \mathrm{m}^{3}\right)$ for $\mathrm{SO}_{2}$. 
Table 3. Descriptive statistics of average measured pollutant concentration $\left(\mu \mathrm{g} / \mathrm{m}^{3}\right)$ at 10 sites during March 2011 to February 2012.

\begin{tabular}{|c|c|c|c|c|c|c|c|c|c|c|c|c|c|c|c|c|}
\hline & \multirow{2}{*}{$\sum_{\Sigma}^{\mathbb{\Xi}}$} & \multicolumn{2}{|c|}{$\begin{array}{l}\text { 95\% Confidence } \\
\text { Interval for Mean }\end{array}$} & \multirow{2}{*}{ 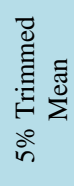 } & \multirow{2}{*}{ 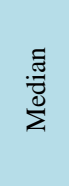 } & \multirow{2}{*}{ 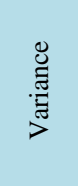 } & \multirow{2}{*}{ 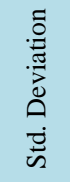 } & \multirow{2}{*}{ 当 } & \multirow{2}{*}{$\begin{array}{l}\text { 夏 } \\
\text { 离 } \\
\text { 劣 }\end{array}$} & \multirow{2}{*}{ 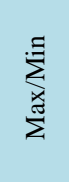 } & \multirow{2}{*}{ 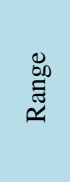 } & \multirow{2}{*}{ 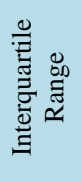 } & \multirow{2}{*}{ 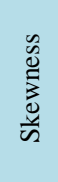 } & \multirow{2}{*}{ 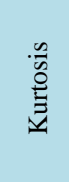 } & \multirow{2}{*}{ 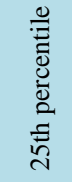 } & \multirow{2}{*}{ 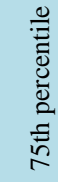 } \\
\hline & & $\begin{array}{l}\text { Lower } \\
\text { Bound }\end{array}$ & $\begin{array}{l}\text { Upper } \\
\text { Bound }\end{array}$ & & & & & & & & & & & & & \\
\hline $\mathrm{H}_{2} \mathrm{~S}$ & 5.5 & 2.2 & 5.6 & 3.8 & 3.8 & 8.0 & 2.4 & 3.9 & 7.5 & 2.0 & 6.3 & 4.0 & 0.3 & -0.6 & 4.6 & 6.3 \\
\hline $\mathrm{SO}_{2}$ & 13.4 & 6.5 & 15.4 & 10.8 & 11.4 & 62.5 & 6.3 & 8.8 & 20.2 & 14.4 & 16.0 & 9.4 & 0.3 & 0.1 & 10.7 & 15.4 \\
\hline $\mathrm{O}_{3}$ & 42.8 & 21.7 & 46.8 & 34.2 & 36.0 & 339.9 & 16.3 & 27.1 & 65.0 & 8.7 & 41.2 & 28.2 & 0.1 & -0.3 & 32.4 & 51.0 \\
\hline $\mathrm{NH}_{3}$ & 4.8 & 2.1 & 5.0 & 3.5 & 3.7 & 4.3 & 1.9 & 3.0 & 8.0 & 3.8 & 4.9 & 3.2 & 0.0 & -0.6 & 3.7 & 5.8 \\
\hline $\mathrm{NO}_{2}$ & 28.9 & 12.8 & 29.0 & 20.8 & 20.6 & 163.7 & 11.4 & 21.1 & 35.6 & 2.3 & 28.3 & 20.0 & 0.1 & -0.7 & 24.3 & 33.5 \\
\hline NO & 42.4 & 16.0 & 42.6 & 28.5 & 24.3 & 409.1 & 18.6 & 25.7 & 62.8 & 4.3 & 52.9 & 29.3 & 0.8 & 0.7 & 32.1 & 53.0 \\
\hline Benzene & 2.5 & 1.4 & 2.8 & 2.0 & 1.9 & 1.2 & 1.0 & 1.8 & 3.7 & 2.2 & 2.7 & 1.6 & 0.4 & -0.6 & 2.0 & 3.1 \\
\hline Toluene & 15.7 & 7.5 & 18.3 & 12.6 & 11.8 & 64.1 & 7.5 & 9.1 & 26.9 & 3.2 & 22.2 & 11.4 & 0.6 & 0.1 & 10.7 & 20.4 \\
\hline N-Octane & 1.3 & 0.7 & 1.4 & 1.0 & 1.0 & 0.3 & 0.5 & 0.8 & 1.8 & 3.6 & 1.3 & 0.8 & 0.2 & -0.8 & 1.0 & 1.5 \\
\hline Ethyle-Benzene & 4.6 & 2.2 & 5.2 & 3.7 & 3.5 & 5.4 & 2.1 & 2.4 & 7.4 & 10.9 & 6.0 & 3.5 & 0.4 & -0.6 & 3.2 & 6.0 \\
\hline m\&p Xylene & 18.1 & 9.0 & 20.7 & 14.6 & 13.8 & 79.7 & 8.2 & 10.5 & 29.1 & 2.9 & 23.6 & 12.8 & 0.4 & -0.4 & 12.4 & 23.6 \\
\hline O-Xylene & 7.3 & 3.7 & 8.2 & 5.9 & 5.6 & 12.1 & 3.2 & 4.3 & 11.4 & 2.8 & 9.2 & 5.1 & 0.3 & -0.5 & 5.1 & 9.4 \\
\hline Nonane & 1.1 & 0.3 & 1.3 & 0.8 & 0.7 & 0.6 & 0.7 & 0.6 & 2.6 & 4.3 & 2.3 & 0.6 & 2.0 & 4.7 & 0.7 & 1.2 \\
\hline
\end{tabular}

The two percentile points define the upper and lower tails of data. The range indicates the difference between the maximum and minimum measured values. Interquartile represents the difference between the 75th and 25th percentile. Skewness number measures to what extent the distribution of values deviates from symmetry around the mean. Kurtosis number measures the "peakedness" or the "flatness" of a distribution. A positive kurtosis indicates a shape flatter than normal.

4) The maximum measured concentration $\left(7.5 \mu \mathrm{g} / \mathrm{m}^{3}\right)$ of $\mathrm{H}_{2} \mathrm{~S}$ is almost within the yearly KEPA standard for residential areas $\left(8 \mu \mathrm{g} / \mathrm{m}^{3}\right)$ for $\mathrm{H}_{2} \mathrm{~S}$.

5) The maximum measured concentration $\left(3.6 \mu \mathrm{g} / \mathrm{m}^{3}\right)$ of Benzene is less than the US-EPA annual threshold (5 $\left.\mu \mathrm{g} / \mathrm{m}^{3}\right)$.

\subsection{Influence of Seasons on the Concentration of Pollutants}

Time-series of monthly average concentration values of measured pollutants are presented in Figure 6. The seasonal variation in ambient levels varies from component to component. For example, $\mathrm{SO}_{2}$ during the winter season, reflects an increase in emissions $\left(16.3 \mu \mathrm{g} / \mathrm{m}^{3}\right)$ associated with domestic heating in Kuwait city and a decrease in the rate of the gas-phase loss of $\mathrm{SO}_{2}$ via chemical conversion to sulfate or in part a result of short-range transport of $\mathrm{SO}_{2}$ from oil fields., while a dramatic decrease during the summer is mainly associated with prevailing wind direction NW that transports the $\mathrm{SO}_{2}$ from oil fields away from Kuwait city [6]. The change in "normality" behavior between winter and summer months, an increase of concentrations up to $6.8 \mu \mathrm{g} / \mathrm{m}^{3} \mathrm{on}$ average, may also be explained considering that $\mathrm{SO}_{2}$ emissions may be likely associated to the nearby Power Plant located upwind of the city.

Similar, high concentrations of $\mathrm{NO}$ and $\mathrm{NO}_{2}$ were recorded for the winter period $\left(43.3\right.$ and $35 \mu \mathrm{g} / \mathrm{m}^{3}$, respectively); i.e., dry season for the city. On average, increase of $\mathrm{NO}$ and $\mathrm{NO}_{2}$ concentrations between winter and summer months reached up to 34 and $25.6 \mu \mathrm{g} / \mathrm{m}^{3}$, respectively. Furthermore, the inversion layer, which is quite pronounced during the winter season, traps more pollutants in ambient air and the relatively calmer conditions in dry months due to the preponderance of windless days that favour the accumulation of pollutants. Thus, the seasonality in emissions from the nearby power plants should also be considered. The increased fuel consumption in buildings with increased or decreased temperature is likely to partially contribute to high concentrations of $\mathrm{NO}_{\mathrm{x}}$ and $\mathrm{SO}_{2}$. Their plumes may be emitted below the boundary layer, during early morning, causing them to reach the ground. One other factor, which could account for the elevated amounts of $\mathrm{NO}$ and $\mathrm{NO}_{2}$ in winter season, is the higher traffic volume due to the seasonal influx of visitors to the city during this period. On the other hand, a factor contributing to the lower levels of air pollution emissions over the summer season could be associated with the fact that the majority of the population in Kuwait, especially the non-Kuwaiti professionals, leaves the State for summer vacation. This will considerably reduce the traffic contribution to air pollution 

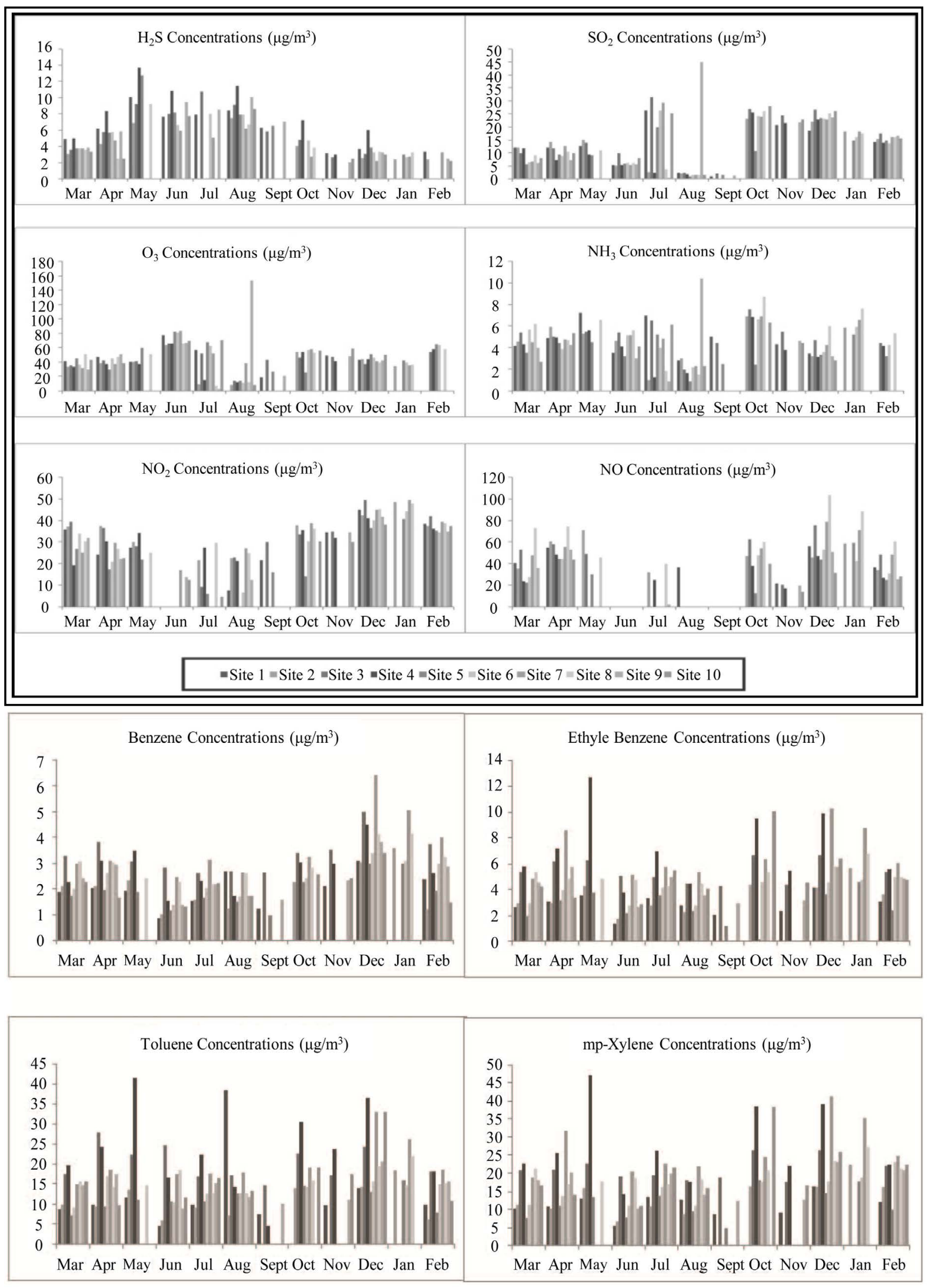

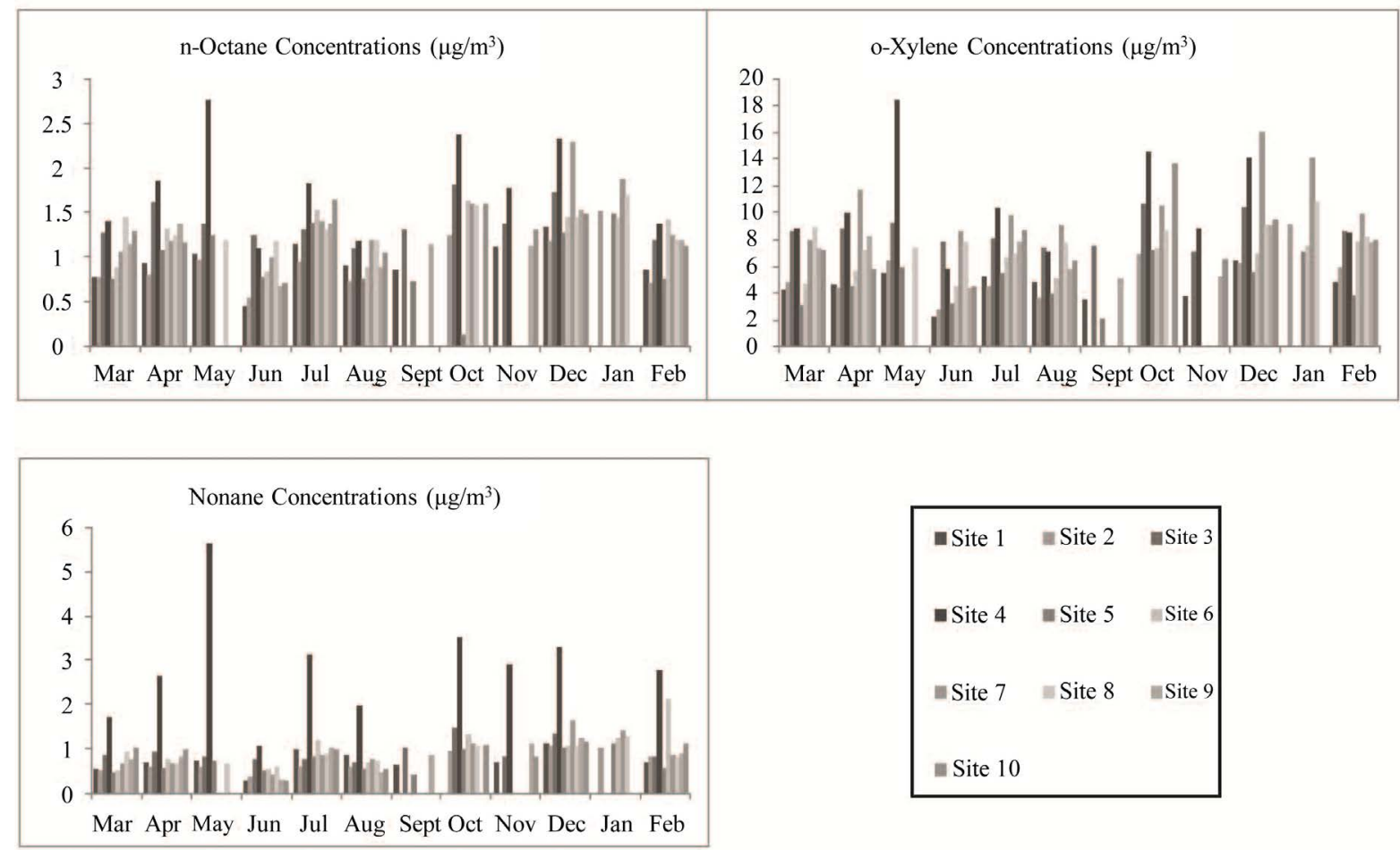

Figure 5. Concentrations of measured pollutants.

emissions over this month (9.5, 9.4 and $9.3 \mu \mathrm{g} / \mathrm{m}^{3}$ for $\mathrm{SO}_{2}, \mathrm{NO}_{2}$ and $\mathrm{NO}$, respectively).

The minimum average values of $\mathrm{NH}_{3}$ and $\mathrm{H}_{2} \mathrm{~S}$ occur in fall. The seasonal change seems to be limited and does not reflect the impact of meteorological factors such as humidity and intensity of winds. $\mathrm{H}_{2} \mathrm{~S}$ and $\mathrm{NH}_{3}$ concentrations could be a result of old-closed landfill sites in the vicinity of the surrounding areas (personnel communication with K-EPA). However, agricultural activities, in particular street plantation, could be the dominant source of $\mathrm{NH}_{3}$ emissions to the atmosphere.

High concentrations of $\mathrm{O}_{3}\left(45.8 \mu \mathrm{g} / \mathrm{m}^{3}\right.$, on average) were recorded for the summer period, the hot season in Kuwait. This is a major concern with high ambient temperatures that induce ozone formation. Generally, increase in power consumption in the summer, reaching up to 10,890 MW (personnel communication with Ministry of Electricity and Water), due to the increased use of indoor air conditioning, results in increase in emission rate of $\mathrm{O}_{3}$.

For Volatile Organic Compounds (VOC), the seasonal changes of n-Octane and Nonane pollutants seem to be limited and do not reflect the impact of meteorological factors such as humidity and intensity of wind or traffic factor. The concentrations of Toluene ranged from 9.1 to $26.9 \mu \mathrm{g} / \mathrm{m}^{3}$, with slight increase of concentrations during winter season $\left(15.9 \mu \mathrm{g} / \mathrm{m}^{3}\right)$ and decrease in fall season $\left(8.9 \mu \mathrm{g} / \mathrm{m}^{3}\right)$. Similarly, the concentrations of Benzene, Ethyl-Benzene, o-Xylene and m\&p-Xylene showed slight increase of concentrations during winter season (2.96, 4.8, 7.5 and $19.5 \mu \mathrm{g} / \mathrm{m}^{3}$, respectively) compared to the lower measured concentrations in fall season (1.4, 2.6, 4.3 and $10.83 \mu \mathrm{g} / \mathrm{m}^{3}$, respectively). In winter season the prevailing southeast wind direction seems to be more effective in diffusing VOCs plume from the downwind emission sources such as the refineries and oil fields to the Kuwait city. Also higher traffic emissions contribution is particularly evident in winter season. Generally speaking, the measured volatile organic compounds seem to behave in a way similar to each other, and the main source of VOC pollutants in Kuwait city comes from motor vehicles, although industrial sources are also relevant [6]. However, the low measured concentrations of VOCs indicate that they mostly decay before reaching the city, thus confirming that the contribution of the oil industry sources in Kuwait is minimal. For example, the Xylene value being much higher than Benzene may be interesting since it indicates either Xylene emission sources are different from those of Benzene, or the same source emitting the various compounds at different rates. 

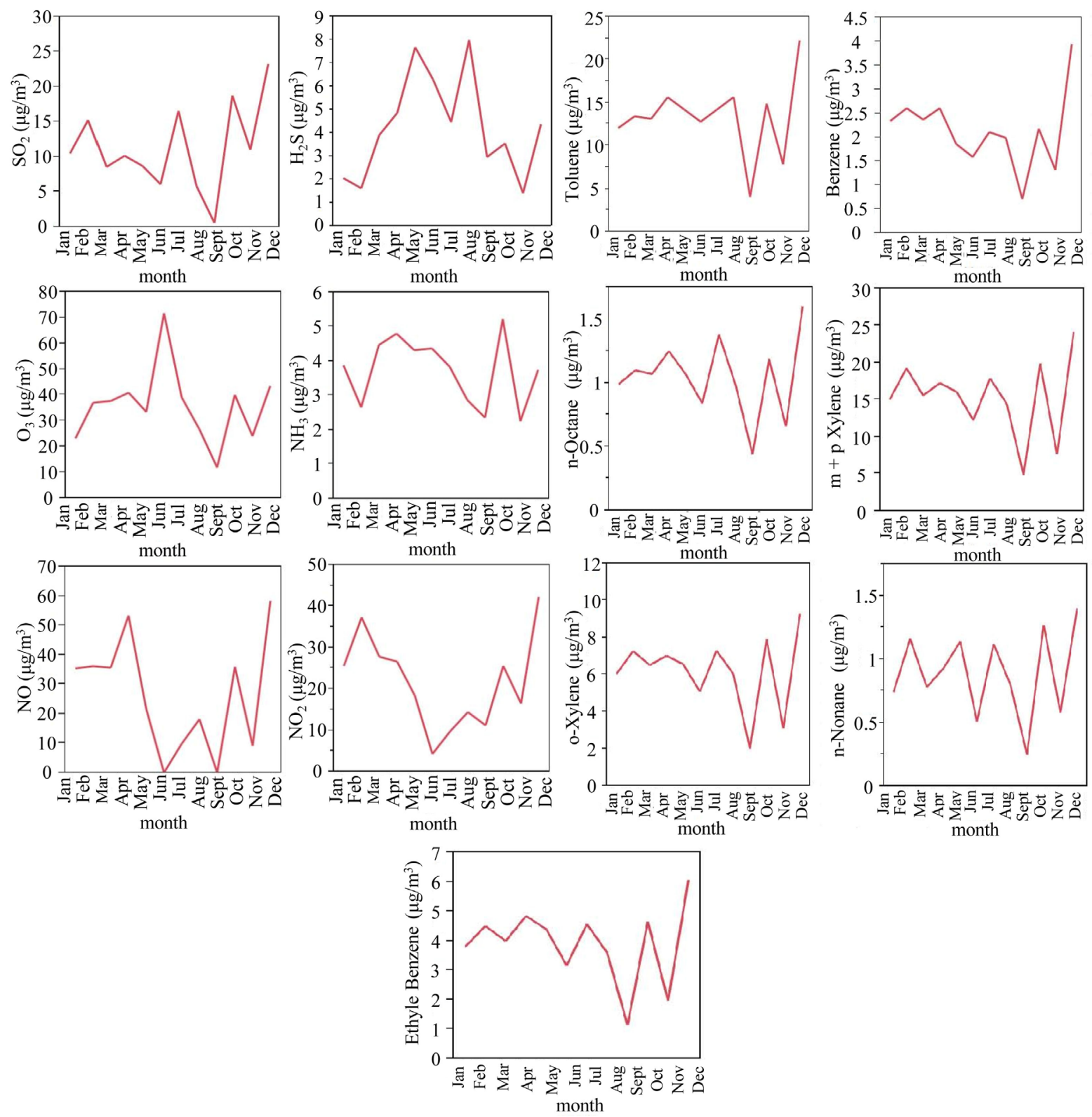

Figure 6. Average monthly variation of measured pollutants.

\subsection{Analysis of Correlations between the Different Pollutants}

Table 4 presents the seasonal analysis of correlations of the measured pollutants. The correlations analysis showed that in winter season $\mathrm{SO}_{2}$ and $\mathrm{O}_{3}$ are strongly correlated $(\mathrm{r}>0.7)$ with $\mathrm{NO}_{2}$ and $\mathrm{NH}_{3}$, respectively, while in summer season $\mathrm{SO}_{2}$ and $\mathrm{NH}_{3}$ are strongly correlated with $\mathrm{O}_{3}$ and $\mathrm{NO}$, respectively. In fall season $\mathrm{O}_{3}$ and $\mathrm{NO}_{2}$ are strongly correlated with $\mathrm{NO}_{2}$ and $\mathrm{NO}$, respectively. However, VOC pollutants showed strongest correlation among themselves, especially Toluene with Xylene, indicating sources in common (traffic emissions). As stated by Costabilea et al. [13] the lowest correlation values are associated to residential emissions and the highest to traffic emissions. The comparison between VOCs correlation ( $\mathrm{r}$ ) with $\mathrm{NO}_{2}$ (they are stronger in summer season) may be a further evidence of the shared traffic sources. On the other hand, several pollutants show significant negative correlations with meteorological factors such as temperature, humidity, wind speed, and wind direction. For example $\mathrm{O}_{3}$ showed strong negative correlation with ambient temperature in winter season and strong positive correlation in fall season. 
Table 4. Correlation coefficient, $r$.

\begin{tabular}{|c|c|c|c|c|c|c|c|c|c|c|c|c|c|c|c|c|c|}
\hline \multicolumn{18}{|c|}{ Winter } \\
\hline & 壳 & న్ & ○ & 壳 & ’̌ & Z & 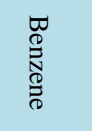 & 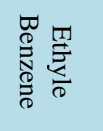 & 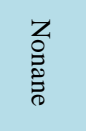 & 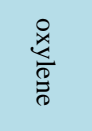 & 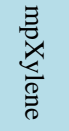 & 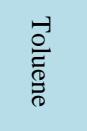 & 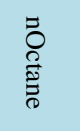 & $\stackrel{0}{9}$ & 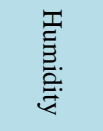 & 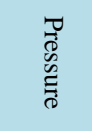 & $\sum \sum_{\infty}$ \\
\hline $\mathrm{H}_{2} \mathrm{~S}$ & 1.00 & & & & & & & & & & & & & & & & \\
\hline $\mathrm{SO}_{2}$ & 0.02 & 1.00 & & & & & & & & & & & & & & & \\
\hline $\mathrm{O}_{3}$ & $0.35-$ & -0.10 & 1.00 & & & & & & & & & & & & & & \\
\hline $\mathrm{NH}_{3}$ & -0.07 & $0.34-$ & $-0.755^{* *}$ & 1.00 & & & & & & & & & & & & & \\
\hline $\mathrm{NO}_{2}$ & 0.130 & $0.768^{* *}$ & -0.01 & $0.16 \quad 1$ & 1.00 & & & & & & & & & & & & \\
\hline NO & -0.45 & -0.17 & 0.07 & $-0.26-0$ & -0.15 & 1.00 & & & & & & & & & & & \\
\hline Benzene & -0.02 & 0.06 & 0.15 & $0.04 \quad 0$ & 0.32 & 0.38 & 1.00 & & & & & & & & & & \\
\hline $\begin{array}{l}\text { Ethyle } \\
\text { Benzene }\end{array}$ & 0.27 & 0.29 & -0.12 & 0.00 & 0.38 & 0.140. & $0.578^{* *}$ & 1.00 & & & & & & & & & \\
\hline Nonane & $0.709^{* *}$ & -0.26 & $-0.01-$ & $\begin{array}{ll}-0.06 & 0\end{array}$ & 0.18 & -0.32 & 0.29 & 0.18 & 1.00 & & & & & & & & \\
\hline oxylene & 0.18 & 0.28 & -0.13 & $0.02 \quad 0$ & 0.35 & 0.210. & $0.620^{* *} 0$ & $0.992^{* *}$ & 0.14 & 1.00 & & & & & & & \\
\hline mpXylene & 0.23 & 0.29 & -0.13 & $0.02 \quad 0$ & 0.37 & 0.160. & $0.590^{* *} 0$ & $0.991^{* *}$ & 0.18 & $0.990^{* *}$ & 1.00 & & & & & & \\
\hline Toluene & $0.14-$ & -0.26 & -0.07 & $0.00 \quad 0$ & 0.15 & $0.27 \quad 0$. & $0.730^{* *}$ & $\begin{array}{ll}0.33 & 0\end{array}$ & $0.747^{* *}$ & 0.34 & 0.35 & 1.00 & & & & & \\
\hline nOctane & $0.26-c$ & $-0.449^{*}$ & -0.06 & $-0.03-0$ & -0.01 & $0.10 \quad 0$. & $0.557^{* *}$ & $\begin{array}{ll}0.19 & 0\end{array}$ & $0.858^{* *}$ & 0.18 & 0.20 & $0.929^{* *}$ & 1.00 & & & & \\
\hline Temp & $-0.40-0$ & $-0.763^{* *}$ & $-0.07-$ & $-0.25-0.7$ & $0.742^{* *} \mathrm{C}$ & $0.577^{* *}$ & -0.03 & -0.25 & -0.01 & -0.19 & -0.20 & 0.22 & 0.25 & 1.00 & & & \\
\hline Humidity & $-0.40-0$ & $-0.724^{* *}$ & -0.05 & $-0.22-0.7$ & $0.728^{* * *} \mathrm{C}$ & $0.555^{* *}-$ & -0.04 & -0.31 & 0.03 & -0.24 & -0.24 & 0.25 & 0.28 & $0.978^{* *}$ & 1.00 & & \\
\hline Pressure & $0.36 \quad 0$ & $0.513^{* *}$ & -0.01 & $0.11 \quad 0.5$ & $.575^{* *}$ & $-0.409^{*}$ & 0.06 & 0.38 & -0.12 & 0.33 & 0.30 & -0.29 & $-0.31-$ & $-0.773^{* *}$ & $-0.889^{* *}$ & ${ }^{*} \quad 1.00$ & \\
\hline WD & $0.40 \quad 0$ & $0.766^{* *}$ & 0.08 & $0.25 \quad 0.7$ & $.742^{* *}-$ & $-0.579^{* *}$ & 0.03 & 0.24 & 0.02 & 0.18 & 0.19 & -0.21 & $-0.25-$ & $-0.999^{* *}$ & $-0.970^{* *}$ & $0.752^{* *}$ & **1.00 \\
\hline WS & $0.15-$ & -0.08 & -0.10 & $-0.09 \quad 0$. & 0.04 & 0.10 & $0.07 \mathrm{c}$ & $0.397^{*}$ & -0.21 & 0.37 & 0.31 & -0.20 & -0.20 & -0.18 & $-0.379^{*}$ & ${ }^{*} 0.761^{* *}$ & ** 0.141 \\
\hline \multicolumn{18}{|c|}{ Spring } \\
\hline & 壳 & ? & ه & 壳 & కై & z & $\begin{array}{l}\mathscr{0} \\
\stackrel{0}{N} \\
0 \\
0\end{array}$ & 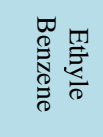 & 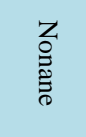 & 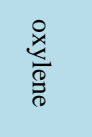 & 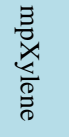 & $\begin{array}{l}\stackrel{-1}{\circ} \\
\stackrel{0}{0} \\
\stackrel{0}{0}\end{array}$ & 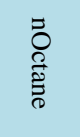 & $\stackrel{\oplus}{\Xi}$ & 焉 & 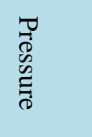 & $\sum \sum_{\infty}$ \\
\hline $\mathrm{H}_{2} \mathrm{~S}$ & 1 & & & & & & & & & & & & & & & & \\
\hline $\mathrm{SO}_{2}$ & 0.327 & 1 & & & & & & & & & & & & & & & \\
\hline $\mathrm{O}_{3}$ & -0.128 & 0.260 & 1 & & & & & & & & & & & & & & \\
\hline $\mathrm{NH}_{3}$ & -0.181 & $0.587^{* *}$ & $0.550^{* * *}$ & 1 & & & & & & & & & & & & & \\
\hline $\mathrm{NO}_{2}$ & -0.401 & $-0.534^{*}$ & $4^{*}-0.610^{*}$ & $0^{* *}-0.176$ & 1 & & & & & & & & & & & & \\
\hline NO & -0.308 & 0.476 & 0.548 & $8 \quad 0.629^{*}$ & * 0.347 & 1 & & & & & & & & & & & \\
\hline Benzene & -0.146 & 0.241 & -0.354 & $\begin{array}{ll}34 & 0.248\end{array}$ & 0.365 & $50.638^{*}$ & 1 & & & & & & & & & & \\
\hline $\begin{array}{l}\text { Ethyle } \\
\text { Benzene }\end{array}$ & $0.476^{*}$ & -0.115 & $5-0.153$ & $33-0.191$ & $1-0.16$ & $67-0.051$ & $10.398^{*}$ & $8^{*}$ & & & & & & & & & \\
\hline Nonane & $0.569^{* *}$ & 0.053 & -0.422 & $2^{*}-0.273$ & $\begin{array}{ll}3 & 0.048\end{array}$ & $8-0.212$ & 20.298 & $80.738^{* *}$ & 1 & & & & & & & & \\
\hline oxylene & $0.443^{*}$ & -0.105 & $5-0.225$ & $25-0.190$ & $0-0.12$ & 260.018 & $0.472^{*}$ & $2^{*} 0.991^{* *}$ & $0.769^{* *}$ & * 1 & & & & & & & \\
\hline mpXylene & $0.436^{*}$ & -0.119 & $9-0.206$ & $6-0.197$ & $7-0.13$ & $35-0.023$ & $30.442^{*}$ & $2^{*} 0.994^{* *}$ & $0.757^{* *}$ & *0.997** & 1 & & & & & & \\
\hline Toluene & 0.130 & 0.118 & -0.139 & $\begin{array}{ll}39 & 0.103\end{array}$ & -0.10 & $08 \quad 0.055$ & $0.730^{* *}$ & ${ }^{* *} 0.741^{* *}$ & ${ }^{*} 0.580^{* *}$ & ${ }^{*} 0.766^{* *} 0$ & $0.746^{* *}$ & 1 & & & & & \\
\hline nOctane & $0.472^{*}$ & $0.382^{*}$ & * -0.327 & $27 \quad 0.030$ & -0.19 & 930.030 & $0.643^{* *}$ & *** $0.656^{* * *}$ & $0.753^{* *}$ & *0.711**0 & $0.680^{* *}$ & $0.744^{* *}$ & 1 & & & & \\
\hline Temp & $0.804^{* *}$ & $0.402^{*}$ & * -0.009 & $9-0.169$ & $9-0.633$ & $3^{* *}-0.423$ & $3-0.147$ & 470.326 & 0.277 & 0.273 & 0.270 & 0.100 & $0.400^{*}$ & 1 & & & \\
\hline Humidity & $-0.834^{* *}$ & $-0.441^{*}$ & $\perp^{*} \quad 0.096$ & $6 \quad 0.174$ & $0.598^{*}$ & $3^{* *} 0.423$ & 0.083 & $3-0.323$ & $3-0.323$ & $3-0.282-$ & -0.276 & -0.109 & $-0.463^{* *}$ & $-0.992^{* *}$ & * 1 & & \\
\hline Pressure & $-0.734^{* *}$ & -0.332 & $2-0.119$ & 190.155 & $0.673^{*}$ & $3^{* *} 0.423$ & 0.236 & $6-0.320$ & $0-0.200$ & -0.252 & -0.254 & -0.083 & -0.296 & $-0.983^{* *}$ & *0.952** & 1 & \\
\hline WD & $-0.677^{* *}$ & -0.281 & $1-0.201$ & $1 \quad 0.144$ & $0.693^{*}$ & $3^{* *} 0.423$ & 0.290 & $0-0.310$ & $0-0.146$ & -0.234 & -0.238 & -0.070 & -0.222 & $2-0.953^{* *}$ & ${ }^{*} 0.908^{* * *} 0$ & $.993^{* * *}$ & 1 \\
\hline WS & $-0.845^{* *}$ & $-0.496^{* *}$ & ** 0.257 & $7 \quad 0.178$ & 0.512 & $2^{*} 0.423$ & -0.041 & $41-0.297$ & $7-0.39^{*}$ & ${ }^{*}-0.282$ & -0.271 & -0.123 & $-0.563^{* *}$ & ${ }^{* *}-0.934^{* *}$ & *0.971 0. & $0.852^{* *} 0.7$ & $.782^{* *} 1$ \\
\hline
\end{tabular}




\begin{tabular}{|c|c|c|c|c|c|c|c|c|c|c|c|c|c|c|c|c|c|}
\hline \multicolumn{18}{|c|}{ Summer } \\
\hline & $\mathrm{H}_{2} \mathrm{~S}$ & $\mathrm{SO}_{2}$ & $\mathrm{O}_{3}$ & $\mathrm{NH}_{3}$ & $\mathrm{NO}_{2}$ & ż & 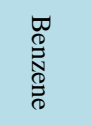 & 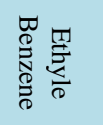 & 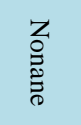 & 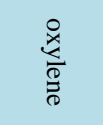 & 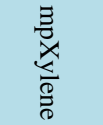 & $\frac{^{-1}}{\stackrel{0}{0}}$ & $\begin{array}{l}\bar{\Xi} \\
\text { ते } \\
\text { Фี }\end{array}$ & $\stackrel{-9}{8}$ & 志 & 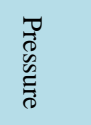 & $\gtreqless \sum$ \\
\hline $\mathrm{H}_{2} \mathrm{~S}$ & 1 & & & & & & & & & & & & & & & & \\
\hline $\mathrm{SO}_{2}$ & 0.126 & 1 & & & & & & & & & & & & & & & \\
\hline $\mathrm{O}_{3}$ & 0.145 & $0.873^{* *}$ & 1 & & & & & & & & & & & & & & \\
\hline $\mathrm{NH}_{3}$ & 0.118 & $0.925^{* *} 0$ & $0.837^{* *}$ & 1 & & & & & & & & & & & & & \\
\hline $\mathrm{NO}_{2}$ & 0.045 & 0.406 & 0.121 & $0.484^{*}$ & 1 & & & & & & & & & & & & \\
\hline NO & -0.214 & 0.611 & $0.690 \mathrm{C}$ & $0.848^{* *}$ & $0.682^{*}$ & 1 & & & & & & & & & & & \\
\hline Benzene & -0.015 & $0.437^{*}$ & 0.266 & 0.383 & $0.583^{* *}$ & 0.616 & 1 & & & & & & & & & & \\
\hline $\begin{array}{l}\text { Ethyle } \\
\text { Benzene }\end{array}$ & -0.101 & 0.040 & 0.005 & 0.136 & $0.560^{*}$ & 0.552 & $0.494^{*}$ & 1 & & & & & & & & & \\
\hline Nonane & $0.608^{* *}$ & 0.316 & 0.097 & 0.271 & 0.432 & $-0.031 \mathrm{c}$ & $0.472^{*}$ & 0.261 & 1 & & & & & & & & \\
\hline oxylene & -0.167 & 0.184 & 0.103 & 0.219 & $0.621^{* *}$ & 0.5840 & $0.673^{* *}($ & $0.873^{* *}$ & 0.320 & 1 & & & & & & & \\
\hline mpXylene & $e-0.124$ & 0.058 & 0.021 & 0.172 & $0.574^{*}$ & 0.565 & $0.500^{*}$ & $0.996^{* *}$ & 0.257 & $0.890^{* *}$ & * 1 & & & & & & \\
\hline Toluene & 0.132 & 0.186 & 0.224 & 0.104 & 0.018 & -0.0940 & $0.667^{* *}$ & -0.1410 & $0.500^{*}$ & * 0.042 & -0.130 & 1 & & & & & \\
\hline nOctane & 0.294 & $0.493^{*}$ & 0.275 & $0.537^{*}$ & $0.747^{* *}$ & 0.6560 & $0.665^{* *} \mathrm{C}$ & $0.538^{* *} 0$ & $0.711^{* *}$ & ${ }^{* *} 0.616^{* *}$ & ${ }^{*} 0.543^{* *}$ & 0.432 & 1 & & & & \\
\hline Temp & 0.072 & 0.401 & 0.2030 & $0.551^{* *}$ & ${ }^{*} 0.585^{* *}$ & 0.190 & 0.276 & 0.321 & 0.332 & 0.236 & 0.349 & -0.004 & 0.383 & 1 & & & \\
\hline Humidity & 0.090 & $0.524^{*}$ & 0.258 & $0.601^{* *}$ & $0.641^{* *}$ & 0.190 & 0.403 & 0.214 & 0.408 & 0.223 & 0.249 & 0.101 & $0.456^{*}$ & $0.954^{* *}$ & 1 & & \\
\hline Pressure & -0.047 & $7-0.246$ & -0.131 & $-0.467^{*}$ & $-0.488^{*}$ & -0.190 & -0.124 & $-0.396^{*}$ & -0.230 & $0-0.227$ & $7-0.416^{*}$ & 0.116 & -0.282 & $-0.958^{* *}$ & $-0.828^{* *}$ & 1 & \\
\hline WD & -0.084 & $4-0.484^{*}-$ & $-0.240-$ & $-0.587^{* *}$ & ${ }^{*}-0.625^{* *}$ & -0.190 & -0.361 & $-0.255-$ & -0.384 & $4-0.230$ & -0.288 & -0.065 & $-0.433^{*}$ & $-0.981^{* *}$ & $-0.994^{* *} 0$ & $0.883^{* *}$ & 1 \\
\hline WS & -0.075 & $-0.423^{*}$ & -0.213 & $-0.561^{* *}$ & ${ }^{*}-0.596^{* *}$ & -0.190 & -0.298 & -0.306 & -0.345 & $5-0.235$ & -0.336 & -0.013 & -0.396 & $-0.999^{* *}$ & $-0.967^{* * *} 0$ & $0.943^{* *} 0$ & $.989^{* *} 1$ \\
\hline
\end{tabular}

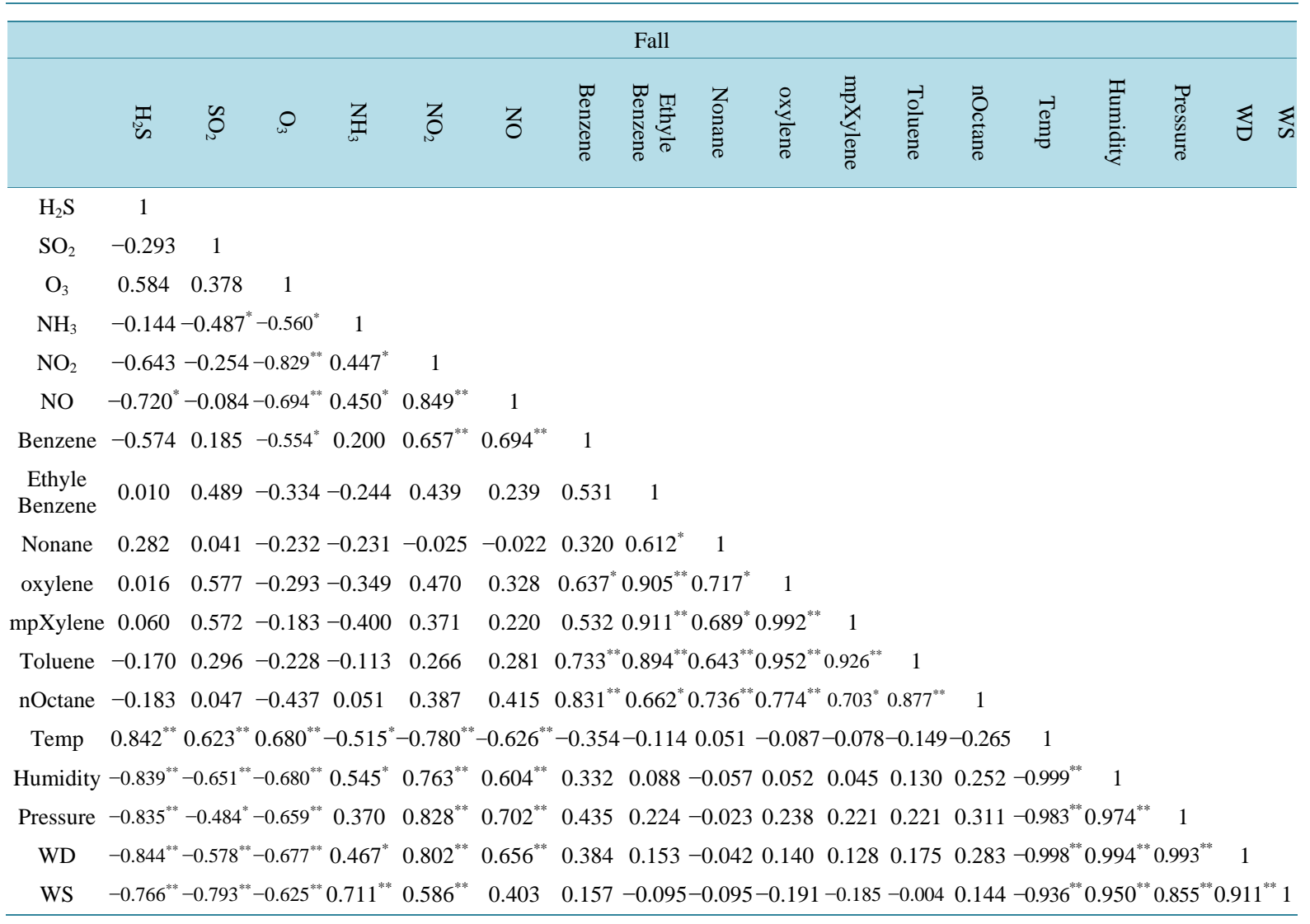

${ }^{* *}$ Correlation is significant at the 0.01 level (2-tailed). ${ }^{*}$ Correlation is significant at the 0.05 level (2-tailed). 
A cluster analysis was also applied to the obtained concentration data for the measured pollutants using Statistics Toolbox function, with average linkages as the criterion for forming clusters of elements. Figure 7 displays three clusters: 1) $\mathrm{H}_{2} \mathrm{~S}, \mathrm{NH}_{3}$, Benzene, N-Octane, Ethyl-Benzene, o-Xylene and Nonane; 2) $\mathrm{SO}_{2}$, Toluene, and $\mathrm{m} \&$ pXylene; 3) $\mathrm{O}_{3}$, $\mathrm{NO}$, and $\mathrm{NO}_{2}$. It is observed, however, that clusters 1 and 2 join together at a relatively lower level implying perhaps an uncommon source, while the long distance of gases in cluster 3 may create an impression that $\mathrm{NO}_{\mathrm{x}}$ may have a different source from other gases; mainly from traffic movement. The cluster analysis also confirms the interaction of $\mathrm{NO}_{\mathrm{x}}$ pollutants with the surrounding environment resulting in ozone formation.

\subsection{Spatial Distribution of Pollutants}

Average resulting contour maps for measured pollutant concentrations in Kuwait city, during March 2011 to February 2012, are illustrated in Figure 8. The spatial distribution patterns of VOCs concentrations are generally similar for all compounds except n-Nonane, with elevated average rates at two spot areas, one at northwest and another at southeast of the city. This may confirm that a significant portion of the VOCs is generated from local sources associated with heavy traffic movement at these areas. The elevated concentration of n-Nonane is found in the southeast sector. This trend is well agreed with the trend of blowing wind in Kuwait; i.e., the prevailing wind blows from the northwest; the northwesterly wind represents $60 \%$ of the total wind directions in Kuwait (Figure 9). This may confirm that the traffic is not a source for n-Nonane.

$\mathrm{SO}_{2}$ concentration distribution showed similarity in spatial distribution patterns of VOC; i.e., the elevated concentrations are found in northeast and southwest sectors. This trend is well agreed with the trend of blowing

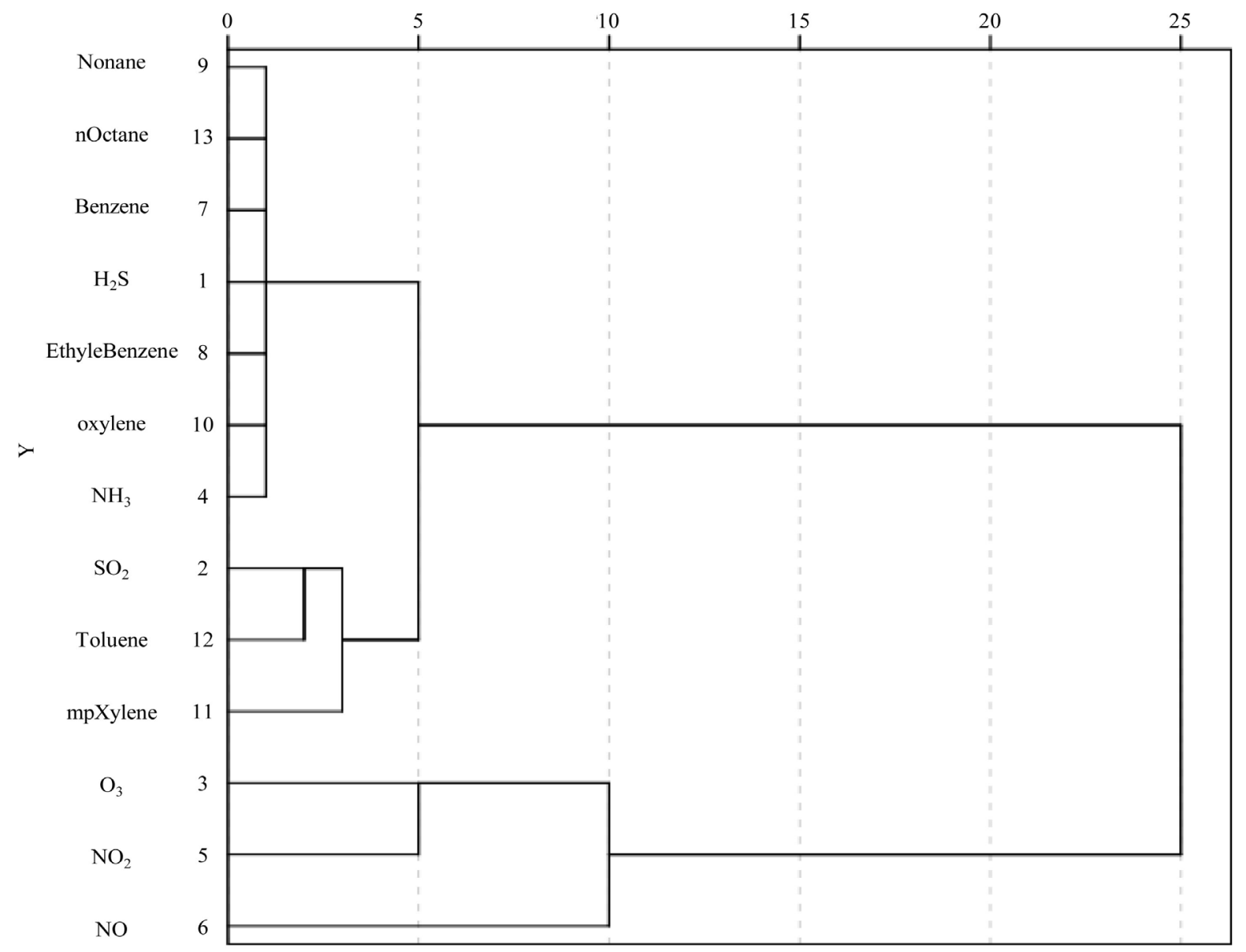

Figure 7. Hierarchical dendogram for measured pollutants (the distances reflect the degree of correlation between different elements). 


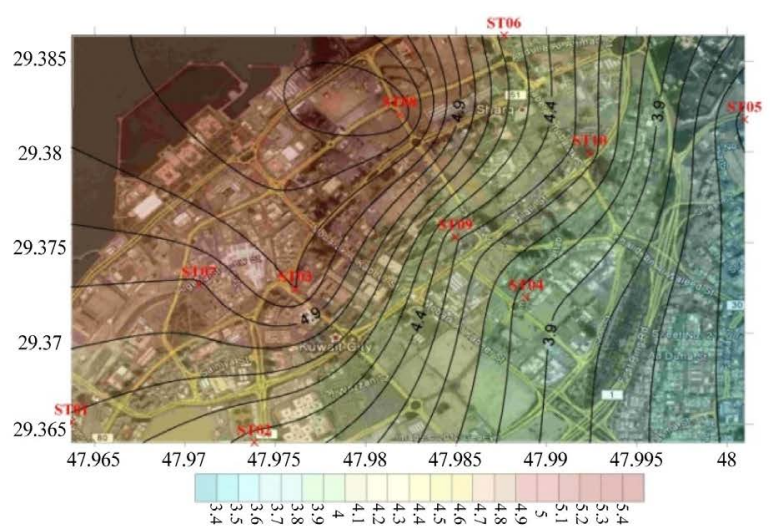

$\mathrm{NH}_{3}$

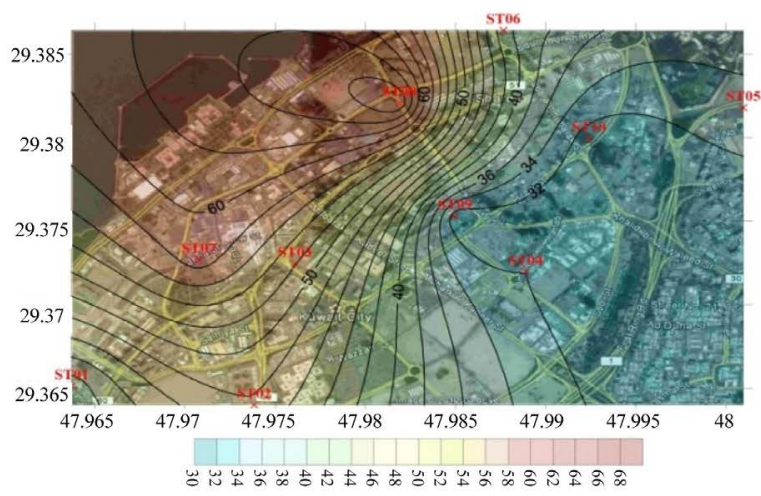

NO

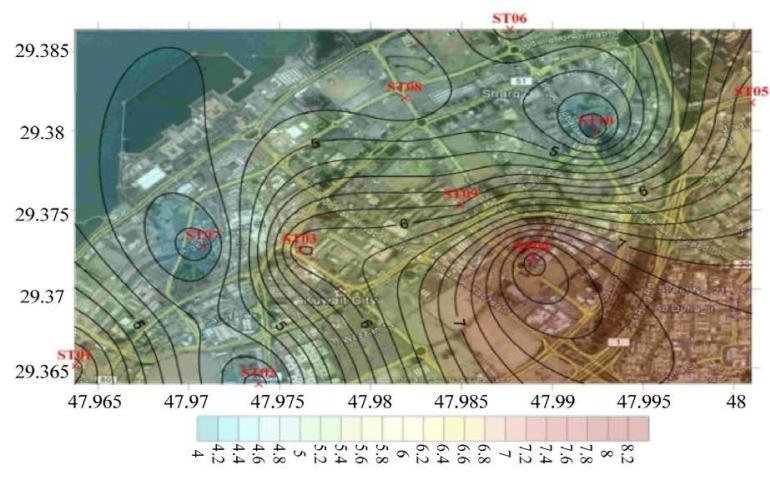

$\mathrm{H}_{2} \mathrm{~S}$

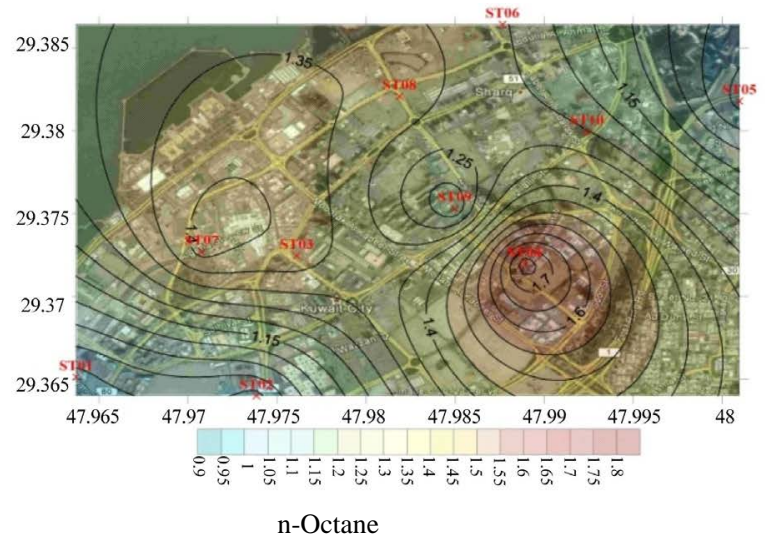

n-Octane

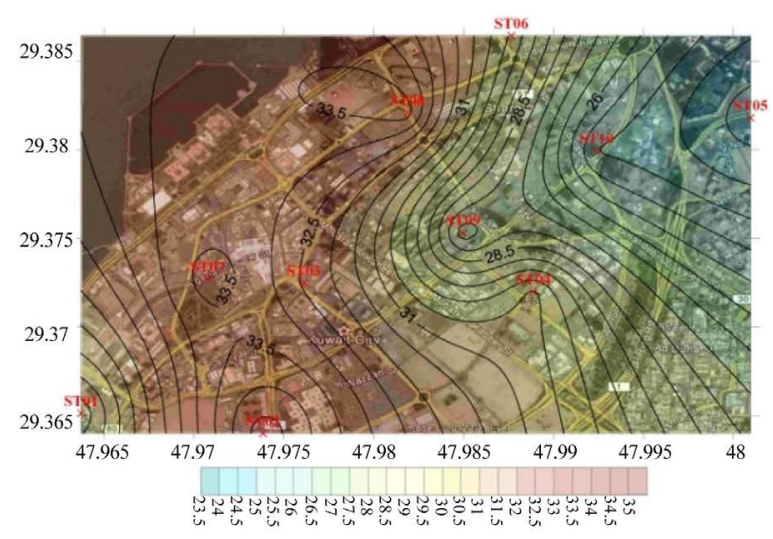

$\mathrm{NO}_{2}$

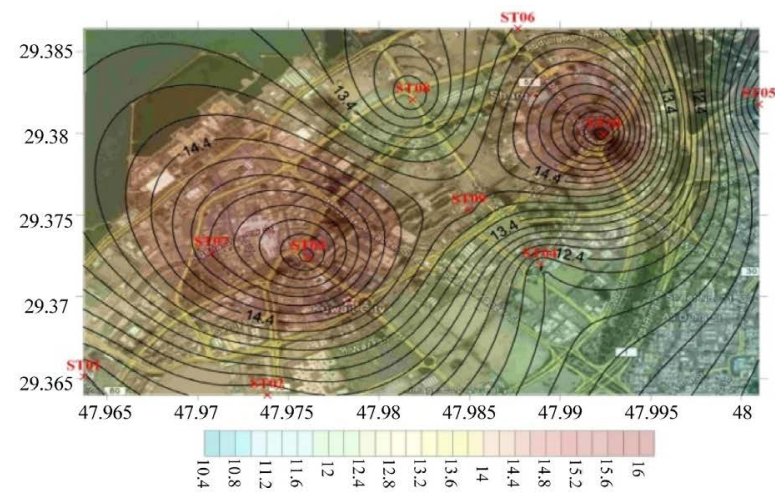

$\mathrm{SO}_{2}$

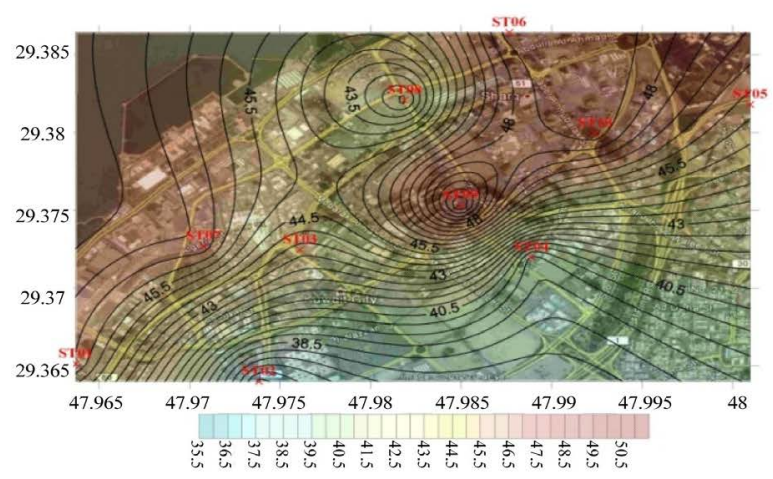

$\mathrm{O}_{3}$

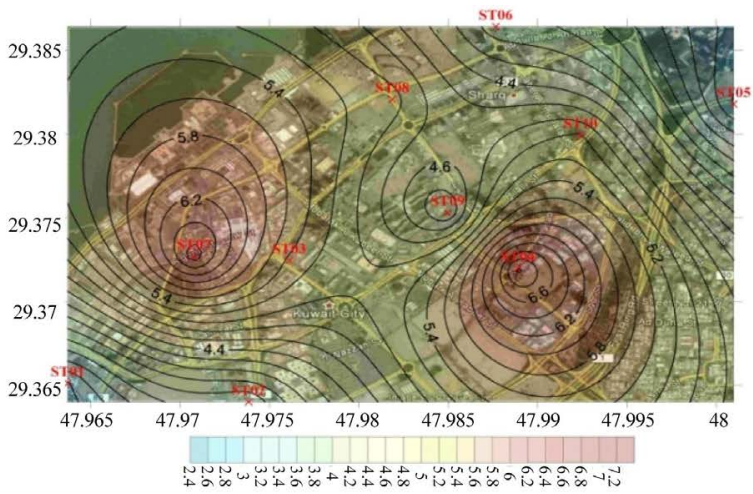

Ethyl Benzene 

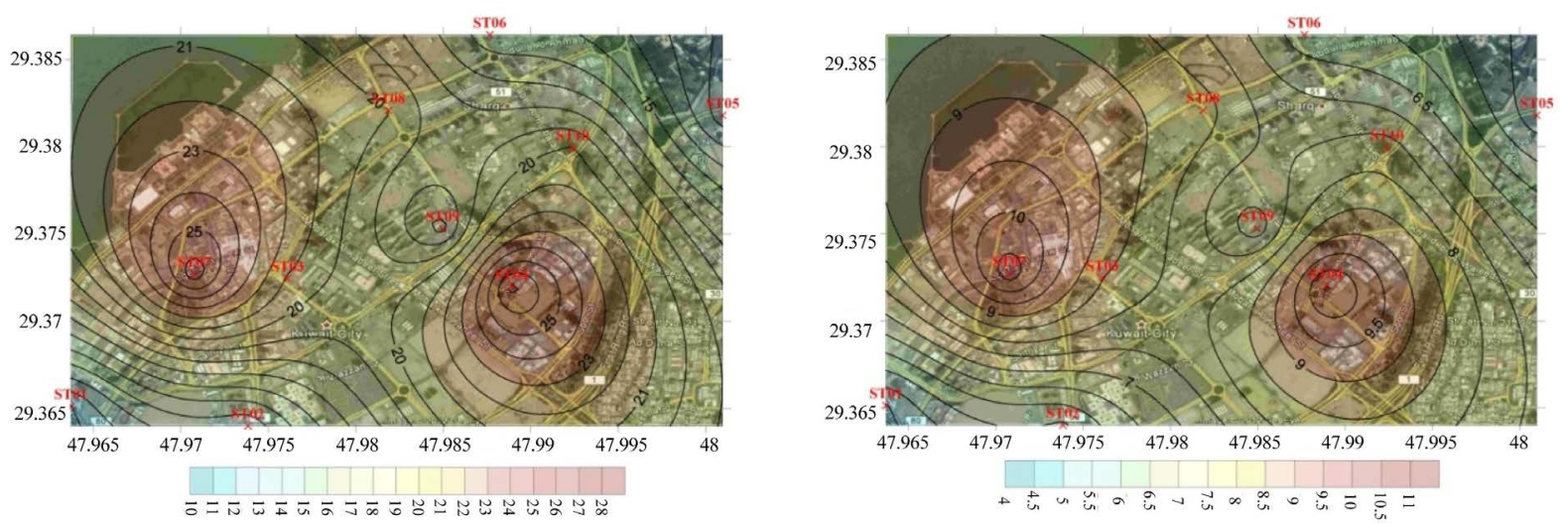

$$
\mathrm{m}+\mathrm{p} \text { Xylene } \quad \text { o-Xylene }
$$

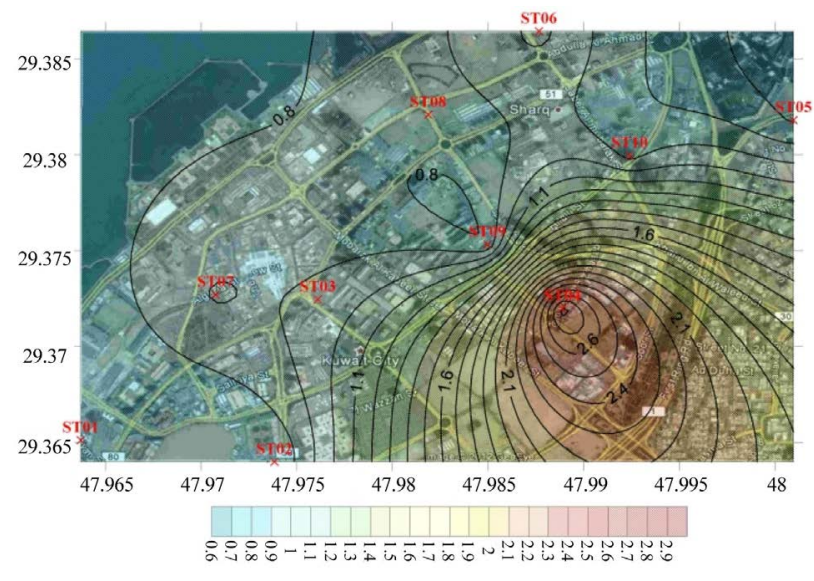

n-Nonane

Figure 8. Contour plots for average annual concentrations of measured pollutants $\left(\mu \mathrm{g} / \mathrm{m}^{3}\right)$ in Kuwait City.

wind in Kuwait; i.e., the wind blows dominantly from the northwest during summer season and, to a lesser extent during the winter season, indicating possible sources for $\mathrm{SO}_{2}$, mainly from the power plants in the northeast of the city and other power plants and refineries in the south.

When the relative magnitudes of air pollutant concentrations are displayed on a map, the local distribution of the pollutants becomes apparent, providing clues to the emission sources. For $\mathrm{NO}$ and $\mathrm{NO}_{2}$, the high concentration area is widely spread in the northwest sector of the city, i.e., downwind of emission sources such as seaport and the northern power stations, indicating external contribution sources beside the traffic movement. $\mathrm{NH}_{3}$ concentration distribution showed similarity in spatial distribution patterns of $\mathrm{NO}_{\mathrm{x}}$, with expected external source due to sanitary water treatment plants, located in the northwest and west of the city, beside ongoing plantation activities along the roads. The elevated concentration of $\mathrm{O}_{3}$ is radiating from the center of the city, indicating that traffic is a significant source of city pollutants. The elevated concentration of $\mathrm{H}_{2} \mathrm{~S}$ is found in the southeast sector where construction activities are going on. Kuwait city in the last 10 years has been exposed to $\mathrm{H}_{2} \mathrm{~S}$ emitted from exposing the underground water during ongoing constructions; the water has been raised up and polluted over old landfills.

\subsection{Air Quality Index (AQI)}

Figure 10 shows the results of AQI values for the hourly average $\mathrm{SO}_{2}, \mathrm{NO}_{2}, \mathrm{CO}, \mathrm{O}_{3}$ and $\mathrm{PM}_{10}$ concentrations for the period from March 2011 to February 2012 at Mansouria AQM station. The calculated AQI values for the hourly average $\mathrm{SO}_{2}$ and $\mathrm{NO}_{2}$ concentrations are categorized as "good" and "moderate" during the study period, except in May and September AQI for $\mathrm{NO}_{2}$ showed 3.1\% of total hourly data as "unhealthy for sensitive” cate 

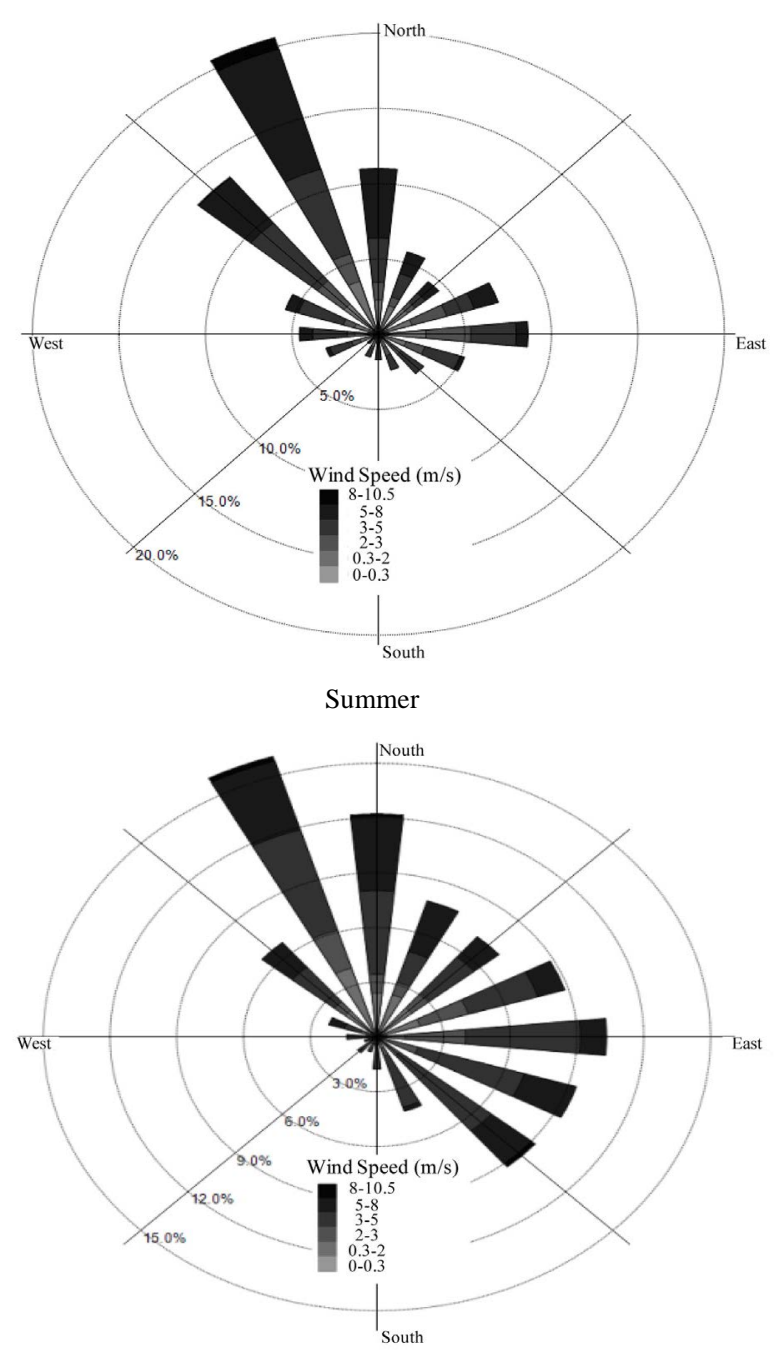

Spring

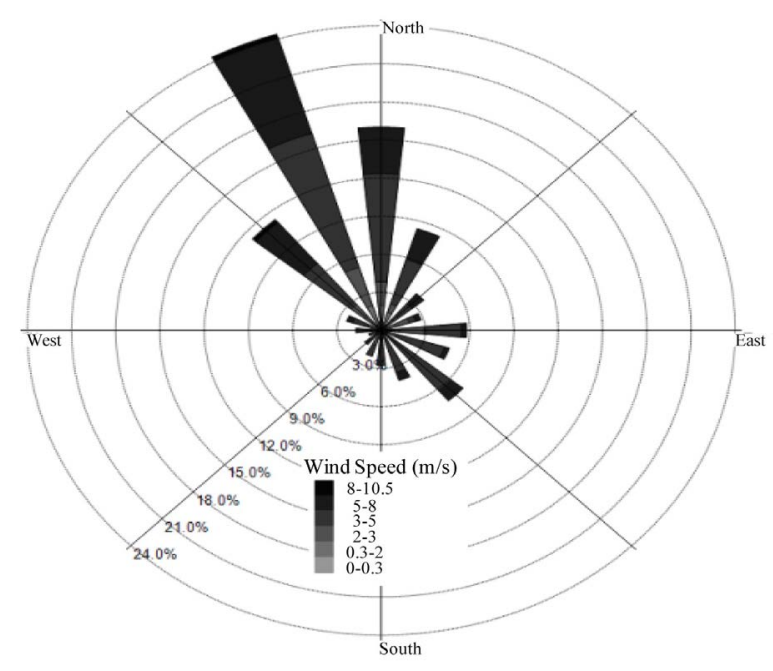

Winter

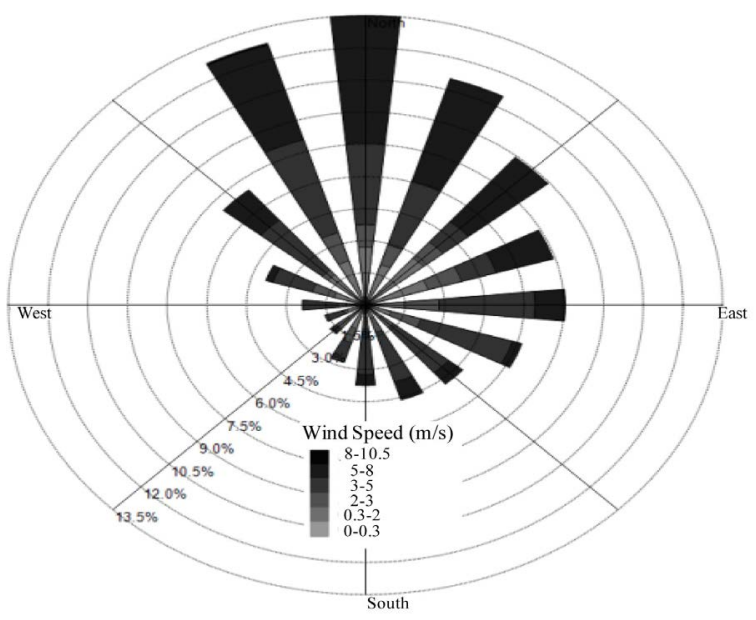

Fall

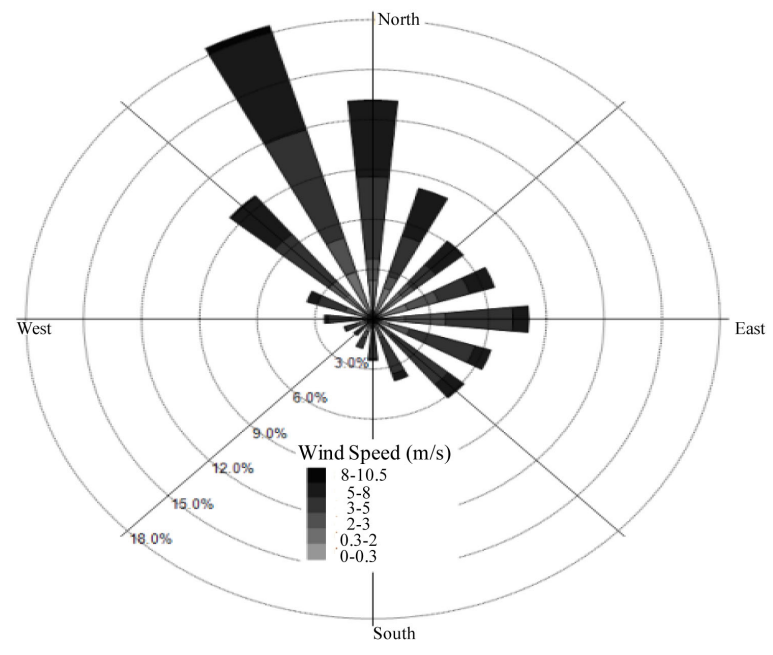

Annual

Figure 9. The seasonal and annual windrose plots for Kuwait City based on metrological data for the period from March 2011 to February 2012. 

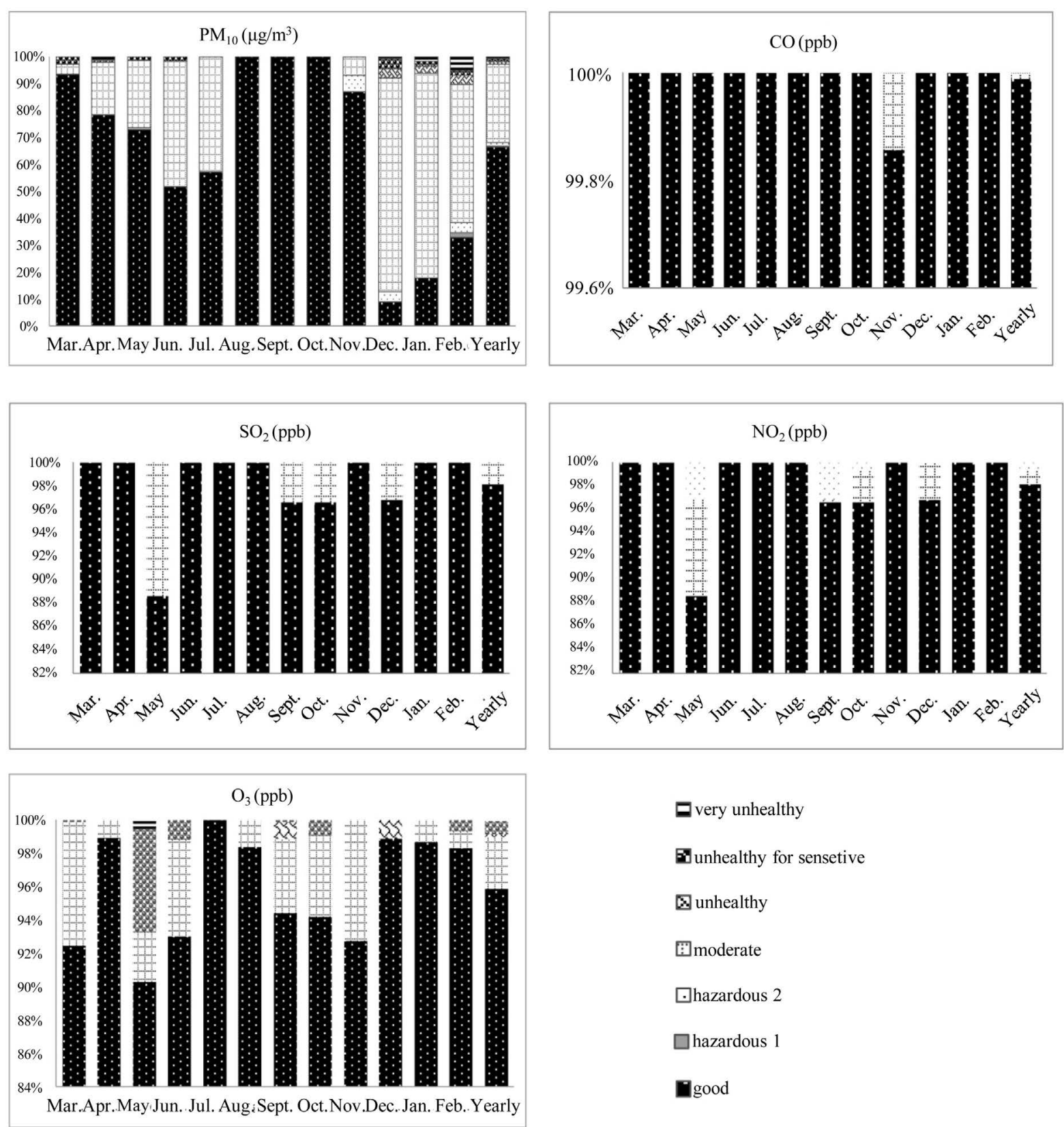

Dvery unhealthy

Wunhealthy for sensetive

Q 0 unhealthy

: : moderate

$\square$ hazardous 2

$\square$ hazardous 1

Шgood

Figure 10. Summary of total annual AQI values, based on 24 h average, for $\mathrm{SO}_{2}, \mathrm{NO}_{2}, \mathrm{CO}, \mathrm{O}_{3}$ and $\mathrm{PM}_{10}$ concentrations in Kuwait City.

gory. Roughly 67 and $29 \%$ of the calculated AQI values for $\mathrm{PM}_{10}$ concentrations are categorized as "good" and "moderate", respectively. In winter season, $51 \%$ - $79 \%$ of the average monthly data was categorized as "moderate”, while in summer season the percentage reduced to $25 \%$ - $46 \%$. The calculated AQI values for the hourly average $\mathrm{O}_{3}$ are categorized mainly as "good" and partially as "moderate", except in May AQI for $\mathrm{O}_{3}$ showed 6\% of total hourly data as "unhealthy for sensitive" category. All calculated AQI values for the hourly average CO concentrations are categorized as "good" during the study period.

The overall assessment of the air quality in Kuwait city, during the months March 2011 to February 2012, indicate that less than $2 \%$ of the calculated hourly average AQI values are categorized as "unhealthy for sensitive" and "very unhealthy". The remaining 98\% of AQI values are categorized as "good" and "moderate".

The AQI was defined taking into account each pollutant separately. The idea behind this approach is that 
dealing with each pollutant separately is easier due to the known health effects resulting from the population's exposure to it. Nevertheless, it seems that up to now Kuwait city has no adverse health effects caused by human exposure to a mixture of air pollutants, although their synergetic impact may not always be easily measured. $\mathrm{PM}_{10}$ may be the only worrying pollutant in the city and its elevated values on some occasions is directly related to the natural dust fallout which is a natural common phenomenon in Kuwait, especially in the summer season.

\section{Conclusions}

The investigation, using multipoint passive samplers, has revealed a good degree of uniformity of pollutants distribution over Kuwait city. The study has provided a preliminary assessment of source contributions and frequency distributions of major air pollutants in Kuwait city. For the measured compounds, it was found that they had low concentrations with no violation of Kuwait EPA air quality standards. Statistical analysis of the data also confirmed that motor vehicles are the largest source emitting nitrogen oxides. Traffic movement is also a main possible emission source of benzene and other VOC pollutants, influenced, however, by a more variable type of emissions related to oil industries. The concentrations of $\mathrm{SO}_{2}$ were strongly influenced by the wind direction and from the nearby power plants due to the use of high sulphur content in locally available crude oil (4\%). The correlation analysis showed that $\mathrm{O}_{3}$ is strongly correlated $(\mathrm{r}>0.7)$ with $\mathrm{NO}_{2}$ in hot season and $\mathrm{SO}_{2}$ in cold season. Furthermore, the inversion layer, which is quite pronounced during the winter season, and temperature variations have clear influence on the seasonal variation in pollutant accumulation in the city, particularly on the concentrations of $\mathrm{NO}_{\mathrm{x}}$ and $\mathrm{SO}_{2}$.

The result shows that air pollution levels in the ambient air quality can be characterized as "good" and "moderate" for $\mathrm{SO}_{2}$ and $\mathrm{CO}$ for all the time, $99 \%$ of the times for $\mathrm{NO}_{2}$ and $\mathrm{O}_{3}$, and $96 \%$ for $\mathrm{PM}_{10}$, during twelve months of measurement (March 2011 to February 2012). The remaining percentage of the time for which $\mathrm{PM}_{10}$ is categorized as unhealthy, is partially related to regular dust fallout in the country.

With such appreciably elevated levels of pollutants in Kuwait city, actions should be taken to reduce emission and studies are needed to assess the role of local sources on long-term environmental impacts. Vehicle emission control could be vital management practice to reduce the input of emissions into the atmosphere. However, for pollutants emitting from oil industrial processes, other precautionary measures should be considered.

\section{Acknowledgements}

This work was supported by Kuwait University Research Grant No. [SE03/08]. The author gratefully acknowledge the assistance, co-operation and logistical support provided by Mr. Ahmed El-Tabei, Mr. Younis Al-Naif and Mr. EmadAl-Khabaz at the Department of Earth and Environmental Sciences.

\section{References}

[1] Al-Mutairi, N. and Koushki, P. (2009) Potential Contribution of Traffic to Air Pollution in the State of Kuwait. American Journal of Environmental Sciences, 5, 218-222. http://dx.doi.org/10.3844/ajessp.2009.218.222

[2] Al-Awadhi, F.A. and Al-Awadhi, S.A. (2006) Bayesian Statistical Modeling for Different Pollutants in the State of Kuwait. Environmetrics, 17, 739-752. http://dx.doi.org/10.1002/env.791

[3] World Bank (2003) World Development Indicators. World Bank Publications, Washington DC.

[4] Matsumoto, K. and Tanaka, H. (1996) Formation and Dissociation of Atmospheric Particulate Nitrate and Chloride: An Approach Based on Phase Equilibrium. Atmospheric Environment, 30, 639-648. http://dx.doi.org/10.1016/1352-2310(95)00290-1

[5] Ettouney, R.S., Abdul-Wahab, S.A. and Elkilani, A.S. (2009) Emissions Inventory, ISCST, and Neural Network Modelling of Air Pollution in Kuwait. International Journal of Environmental Studies, 66, 193-206. http://dx.doi.org/10.1080/00207230902859929

[6] Al-Salem, S.M. and Khan, A.R. (2008) Comparative Assessment of Ambient Air Quality in Two Urban Areas Adjacent to Petroleum Downstream/Upstream Facilities in Kuwait. Brazilian Journal of Chemical Engineering, 25, 683696. http://dx.doi.org/10.1590/S0104-66322008000400006

[7] Ferm, M. and Rodhe, H. (1997) Measurements of Air Concentrations of $\mathrm{SO}_{2}, \mathrm{NO}_{2}$ and $\mathrm{NH}_{3}$ at Rural and Remote Sites in Asia. Journal of Atmospheric Chemistry, 27, 17-29. http://dx.doi.org/10.1023/A:1005816621522

[8] Ayers, G.P., Keywood, M.D., Gillet, R.W., Manins, P.C., Malfroy, H. and Bardsley, T. (1998) Validation of Passive Diffusion Samplers for $\mathrm{SO}_{2}$ and $\mathrm{NO}_{2}$. Atmospheric Environment, 32, 3593-3609. 
http://dx.doi.org/10.1016/S1352-2310(98)00079-X

[9] Ayers, G.P., Peng, L.C., Gillet, R.W. and Fook, L. (2002) Rainwater Composition and Acidity at Five Sites in Malaysia in 1996. Water, Air and Soil Pollution, 133, 15-30. http://dx.doi.org/10.1023/A:1012967614759

[10] Gillett, R.W., Ayers, G.P., Mhwe, T., Selleck, P.W. and Harjan, H. (2000) Concentrations of Nitrogen and Sulfur Species in Gas and Rainwater from Several Sites in Indonesia. Water, Air and Soil Pollution, 120, 205-2015. http://dx.doi.org/10.1023/A:1005223124903

[11] Al-Shayji, K., Lababidi, H.M., Al-Rushoud, D. and Al-Adwani, H. (2008) Development of a Fuzzy Air Quality Performance Indicator. Kuwait Journal of Science and Engineering, 35, 101-126.

[12] US Environmental Protection Agency (2006) Guideline for Reporting of Daily Air Quality_Air Quality Index (AQI). Office of Air Quality Planning and Standards, Research Triangle Park.

[13] Costabilea, F., Bertonia, B., Desantisa, F., Wanga, F., Weiminb, H., Fengleib, L. and Allegrinia, I. (2006) A Preliminary Assessment of Major Air Pollutants in the City of Suzhou, China. Atmospheric Environment, 40, 6380-6395. http://dx.doi.org/10.1016/j.atmosenv.2006.05.056 